(c) 2017, Elsevier. Licensed under the Creative Commons Attribution-NonCommercial-NoDerivatives 4.0 International http://creativecommons.org/licenses/by-nc-nd/4.0/

\title{
Review of Physicochemical Properties and Analytical Characterization of Lignocellulosic Biomass
}

(to be submitted to Renewable and Sustainable Energy Reviews)

Junmeng Cai *,a ${ }^{\text {, Yifeng He }}{ }^{\mathrm{a}}$, Xi Yu ${ }^{\mathrm{b}}$, Scott W. Banks ${ }^{\mathrm{b}}$, Yang Yang ${ }^{\mathrm{b}}$, Xingguang Zhang ${ }^{\mathrm{c}}$, Yang Yu ${ }^{\mathrm{a}}$, Ronghou Liu ${ }^{\mathrm{a}}$, Anthony V. Bridgwater ${ }^{\mathrm{b}}$

${ }^{\text {a }}$ Biomass Energy Engineering Research Center, Key Laboratory of Urban Agriculture (South) of Ministry of Agriculture, School of Agriculture and Biology, Shanghai Jiao Tong University, 800 Dongchuan Road, Shanghai 200240, People's Republic of China

${ }^{\mathrm{b}}$ Bioenergy Research Group, European Bioenergy Research Institute, Aston University, Birmingham, B4 7ET, United Kingdom

${ }^{\mathrm{c}}$ Department of Chemical Engineering, Nanjing Forestry University, 159 Longpan Road, Nanjing 210037, People's Republic of China

* Corresponding author: Junmeng Cai. Tel.: +86-21-34206624; Email: jmcai@sjtu.edu.cn.

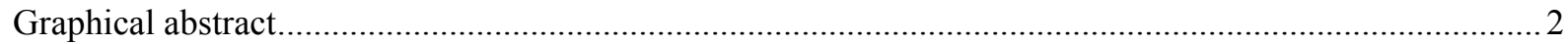

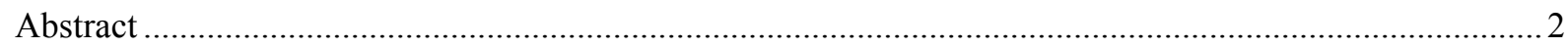

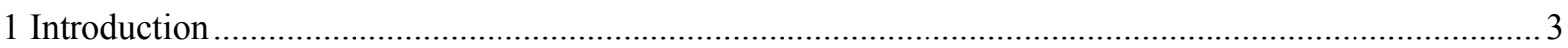

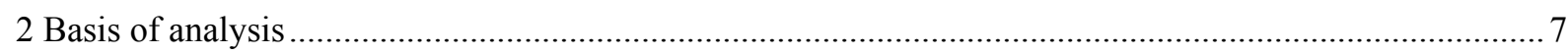

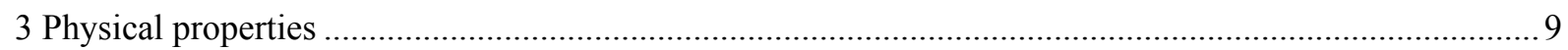

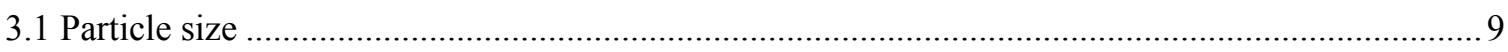

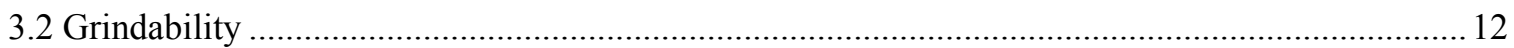

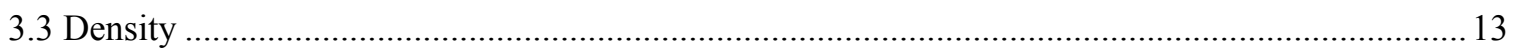

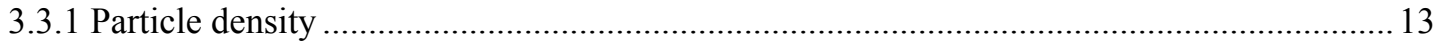

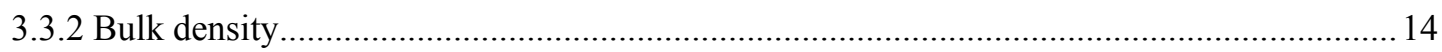

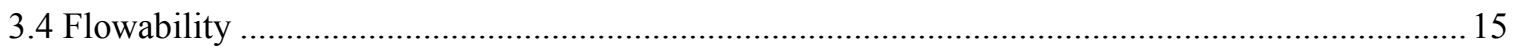

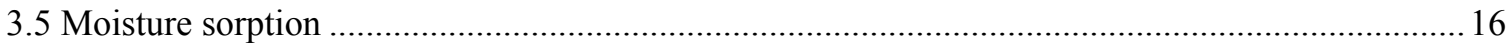

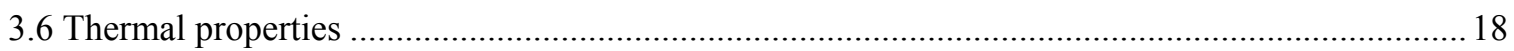

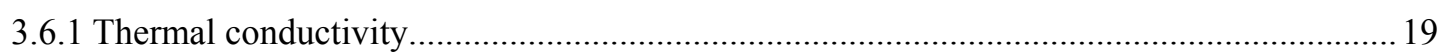

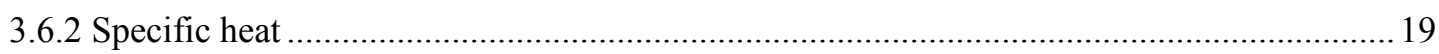

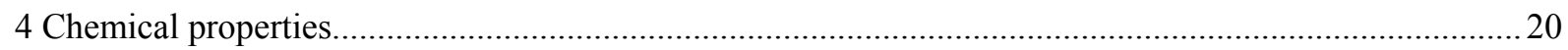

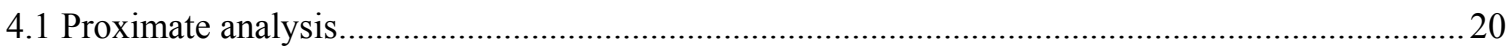

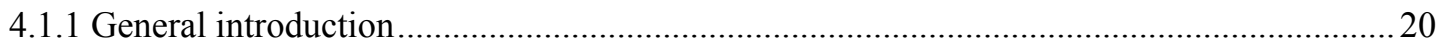


4.1.2 ASTM standard method

4.1.3 Thermogravimetric analysis method ..................................................................... 21

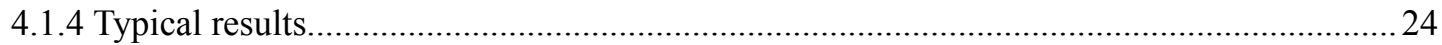

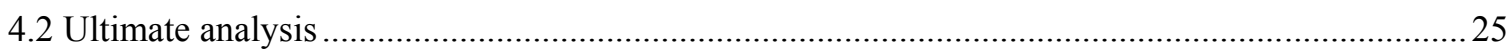

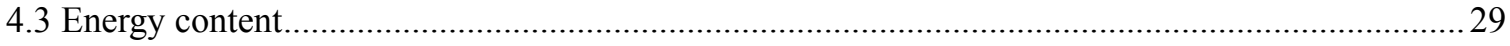

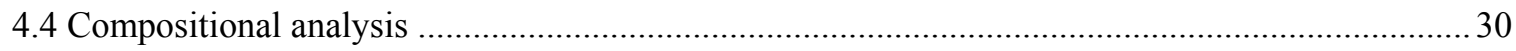

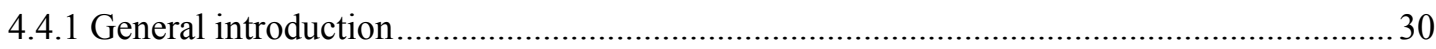

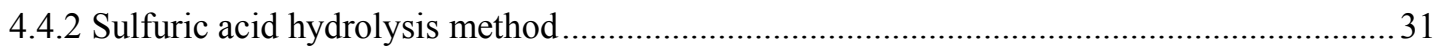

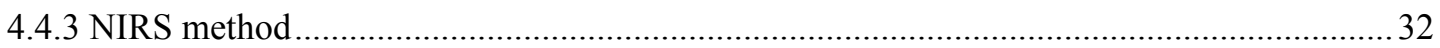

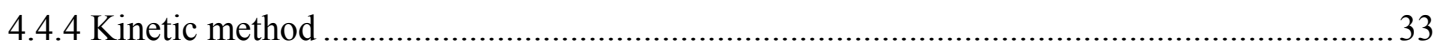

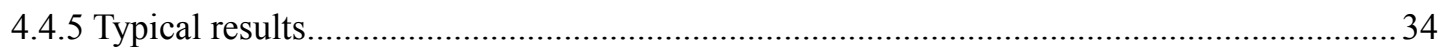

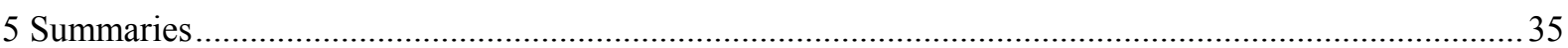

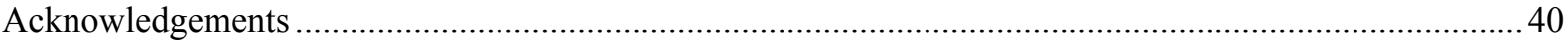

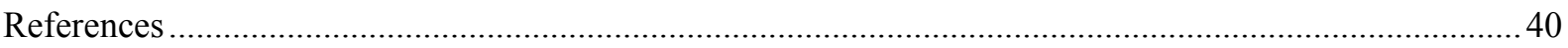

\section{Graphical abstract}

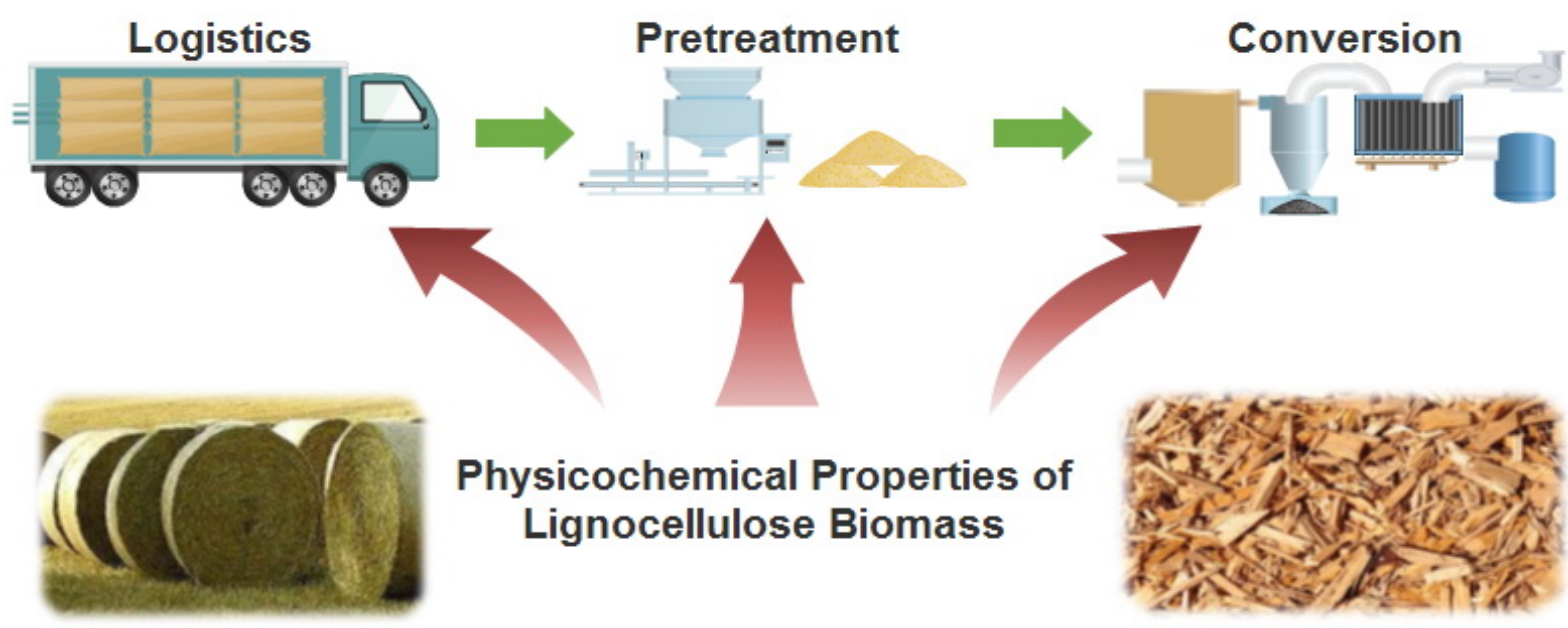

\section{Abstract}

Lignocellulosic biomass is the most abundant and renewable material in the world for the production of biofuels. Using lignocellulosic biomass derived biofuels could reduce reliance on fossil fuels and contribute to climate change mitigation. A profound understanding of the physicochemical properties of lignocellulosic biomass and the analytical characterization methods for those properties is essential for the design and operation of associated biomass conversion processing facilities. The present article aims to present a comprehensive review of physicochemical properties of lignocellulosic biomass, including particle size, grindability, 
density, flowability, moisture sorption, thermal properties, proximate analysis properties, elemental composition, energy content and chemical composition. The corresponding characterization techniques for these properties and their recent development are also presented. This review is intended to provide the readers systematic knowledge in the physicochemical properties of lignocellulosic biomass and characterization techniques for the conversion of biomass and the application of biofuels.

Key words: lignocellulosic biomass; physicochemical properties; biofuel; biomass conversion; analytical characterization

\section{Introduction}

Biofuels offer the prospective to reduce the reliance on use of fossil fuels, address the fuel security and environment issues, and favor some socioeconomic benefits such as sustainable development and creating jobs [1]. According to International Energy Agency, biomass energy accounts for about $14 \%$ of the world's total primary energy supply [2]. Lignocellulosic biomass is the most abundant and renewable material in the world for the production of biofuels [3], which can be used as a fuel resource alternative to fossil resources.

Lignocellulosic biomass refers to plant dry matter, which is mainly composed of cellulose, hemicellulose and lignin [4]. The lignocellulosic biomass feedstocks available for energy purpose are mainly from the following sectors: agriculture, forest, and industry. Table 1 lists various types of lignocellulosic biomass with some examples. Agricultural wastes and forest residues are the most promising biomass feedstocks for their abundance and relatively low cost [5]. 
Table 1. Lignocellulosic biomass feedstocks available for energy purposes

\begin{tabular}{lll}
\hline Supply sector & Type & Examples \\
\hline Agriculture & $\begin{array}{l}\text { Lignocellulosic energy crops } \\
\text { Crop residues }\end{array}$ & $\begin{array}{l}\text { Herbaceous crops (e.g. switchgrass, miscanthus, reed) } \\
\text { crop straw (e.g. rice straw, wheat straw, corn stalk, } \\
\text { cotton stalk) }\end{array}$ \\
& $\begin{array}{l}\text { Oil, sugar and starch energy } \\
\text { crops }\end{array}$ & Rape seed, sugarcane, corn \\
Fodicated forestry & $\begin{array}{l}\text { Short rotation plantations (e.g. willow, poplar, } \\
\text { eucalyptus) }\end{array}$ \\
& Forestry by-products & $\begin{array}{l}\text { Barks; Wood blocks; Wood chips from tops and } \\
\text { branches; Wood chips from thinning; Logs from } \\
\text { thinning }\end{array}$ \\
& Rice husk, sugarcane bagasse, corn cob \\
Industry & Lignocellulosic agro- & industrial residues \\
Wood industry residues & Industrial waste wood; Sawdust from sawmills \\
& Lignocellulosic waste & $\begin{array}{l}\text { Lignocellulosic residues from parks and gardens (e.g. } \\
\text { prunings, grass) }\end{array}$ \\
\hline
\end{tabular}

Traditional use of lignocellulosic biomass has been limited to burning for cooking and heating, which lead to significant negative environmental impacts such as land degradation and desertification [6]. By means of thermochemical or biochemical conversion routes, lignocellulosic biomass can be converted into energy or energy carriers. Thermochemical conversion uses heat and chemical processes to produce energy products from biomass, including combustion, pyrolysis, gasification, and liquefaction [7]. Biochemical conversion of biomass involves the use of bacteria, microorganisms or enzymes to breakdown biomass into gaseous or liquid fuels, such as biogas or bioethanol [8]. Typical biomass conversion technologies and their primary products and end-uses are illustrated in Figure 1. 


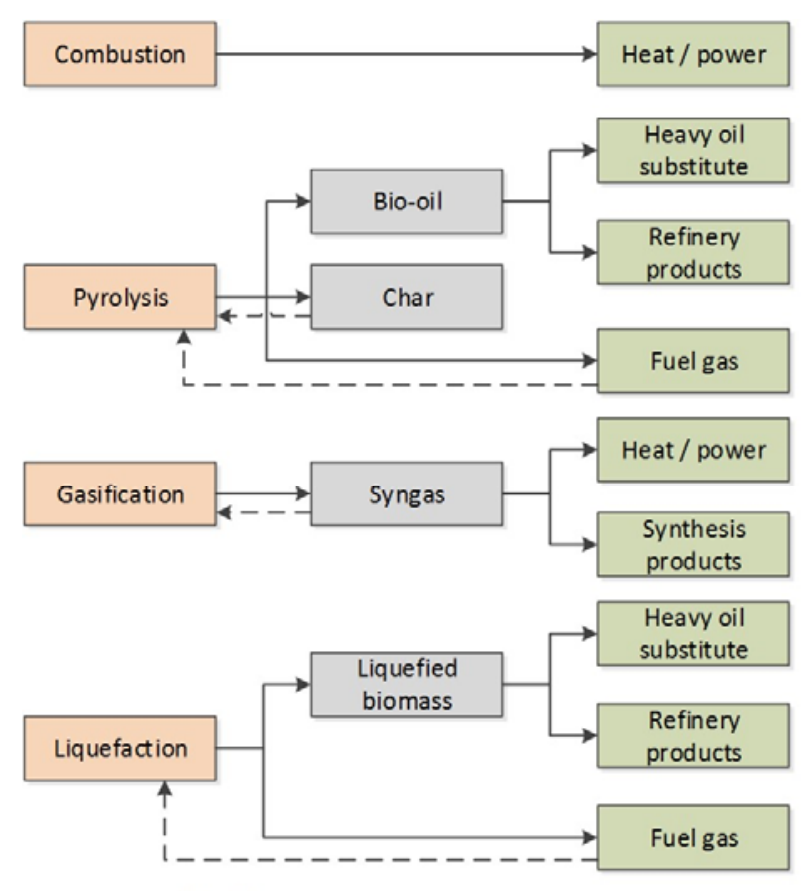

(a) Thermochemical conversion

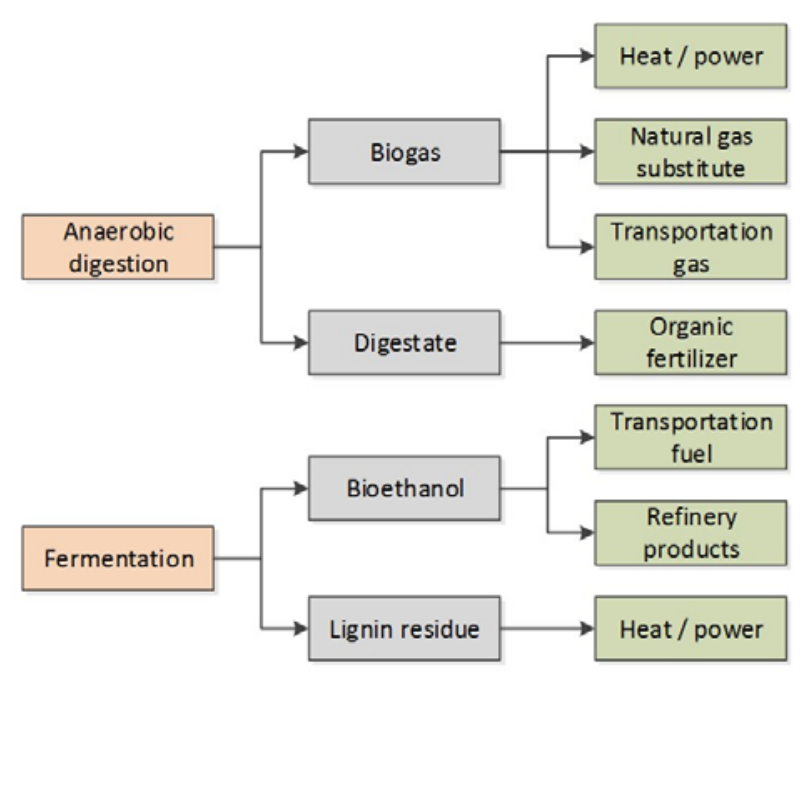

(b) Biochemical conversion

Figure 1. Thermochemical and biochemical conversion of lignocellulosic biomass

The whole biomass-to-biofuel process includes the logistics, pretreatment and conversion processes of lignocellulosic biomass [9]. The logistics process includes the collection, handling, storage and transportation of biomass feedstocks. The pretreatment process contains the drying, grinding and sieving of feedstocks. The conversion process includes feeding, conversion, separation of intermediate products, collection and upgrading and collection of products. The physicochemical properties of lignocellulosic biomass are essential data of reference for the design and implementation of these processes (Figure 2). Table 2 lists the engineering application of these properties $[10,11]$. 


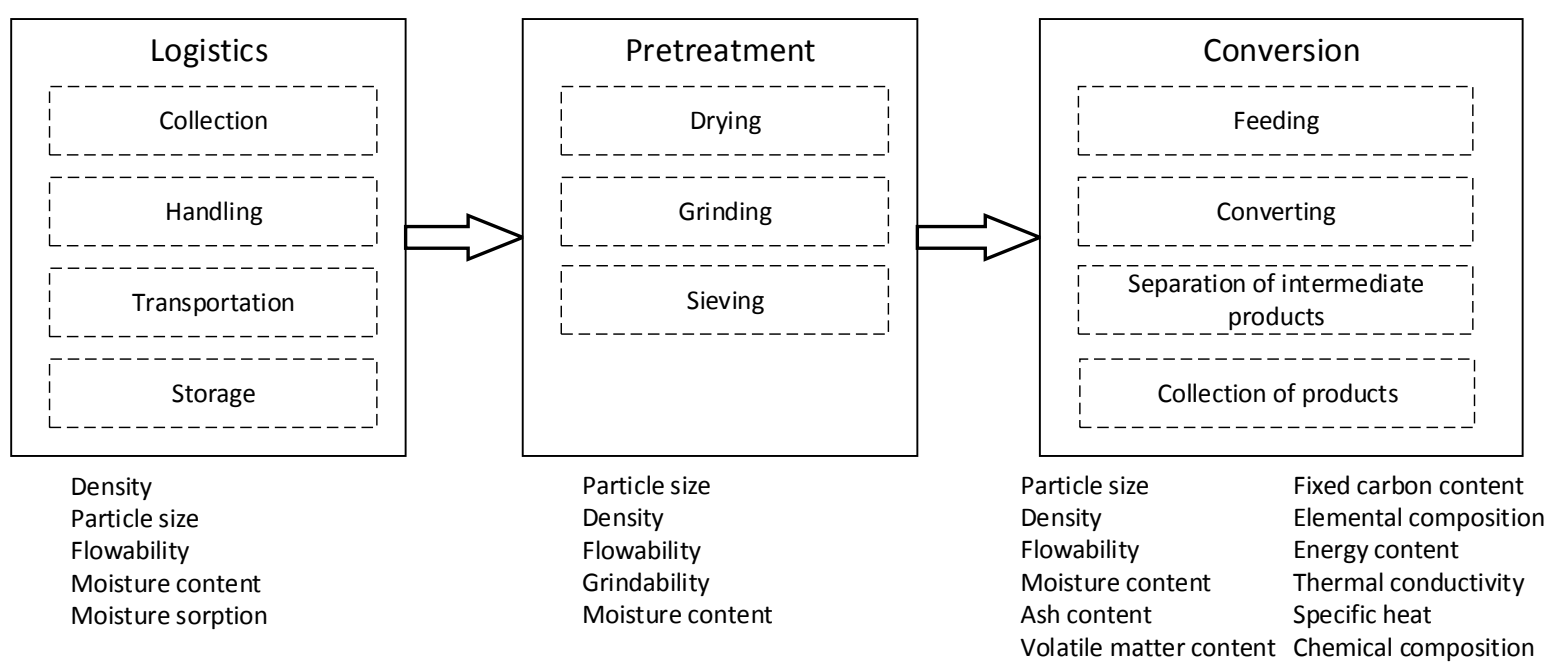

Figure 2. Physicochemical properties of lignocellulosic biomass relevant for different

processes

Table 2. Engineering application of physicochemical properties of lignocellulosic biomass

\begin{tabular}{ll}
\hline Physicochemical properties & Engineering applications \\
\hline Density & Design parameter for handling, storage and transportation facilities \\
Flowability & Design parameter for handling, feeding and storage facilities \\
Grindability & Design parameter for grinding facilities \\
Particle size & Design parameter for feeding, grinding, and storage facilities \\
Moisture sorption & Design parameter for drying and storage facilities \\
Moisture content & Design parameter for drying, handling, storage, and feeding facilities and \\
& conversion processes \\
Ash content & Estimation of the potential risk of slagging and fouling issues during \\
& biomass combustion or gasification \\
Volatile matter content & Conversion efficiency \\
Elemental composition & Conversion efficiency \\
Energy content & Energy recovery efficiency \\
Thermal properties & Thermochemical conversion efficiency \\
Chemical composition & Conversion efficiency \\
\hline
\end{tabular}

Many researchers have investigated the effect of the aforementioned properties of lignocellulosic biomass on its conversion performance [11, 12]. Several studies focuses on the properties of biomass. $\mathrm{Xu}$ et al. [13] reviewed studies of biomass compositions and structure using infrared techniques and discussed the progress and prospects for the applications of those techniques. Lin et al. [14] addressed the relationship between biomass compositions and liquid products from biomass pyrolysis. Räisänen and Athanassiadis [15] presented the basic chemical 
compositions of three forest biomasses (pine, spruce and birch). Arnoult et al. [16] gave a review on miscanthus biomass production and composition for bioenergy use. Isikgor and Becer [17] summarized the cellulose, hemicellulose and lignin contents of various biomasses including hardwood, softwood, agricultural residues and grasses. Vassilev et al. [18] focused on the elemental compositions of biomass including the contents of $\mathrm{C}, \mathrm{O}, \mathrm{H}, \mathrm{N}, \mathrm{Ca}, \mathrm{K}, \mathrm{Si}, \mathrm{Mg}$, Al, S, Fe, P, Cl, Na, Mn, and Ti. Vassilev et al. [19] compared the advantages and disadvantages of compositions of biomass and coal and obtained that the disadvantages of biomass for biofuel prevail over the advantages, but the environmental, economic and social benefits appear to compensate the technological and other barriers. However, there remains no comprehensive compilation of various physicochemical properties of lignocellulosic biomass and the analytical characterization methods for those properties in literature. This review concentrates on the physicochemical properties of lignocellulosic biomass, the analytical characterization methods for those properties, and recent progress in understanding those physicochemical properties.

\section{Basis of analysis}

In research practice, there are four types of bases of analysis commonly used for expressing biomass analysis results, i.e., as received basis, air dried basis, dry basis, and dry ash free basis [20].

As received basis is the means of expressing an analytical result based on the total weight of sample as it arrived at the laboratory and prior to any pre-treatment.

Air dried basis is the means of expressing an analytical result based on the condition in which the sample is in equilibrium with atmospheric humidity. Air dried basis neglects the presence of moisture other than inherent moisture.

Dry basis is the means of expressing an analytical result based on the condition in which biomass is free from moisture. Dry basis leaves all moistures including external and inherent moistures.

Dry ash free basis is the means of expressing an analytical result based on a condition in which the sample is considered to be free from both all moistures and ash. This is frequently 
used in ultimate analysis to show the contents of elements in the organic fractions of the biomass sample.

Figure 3 shows the components of biomass reporting to different bases of analysis.

\begin{tabular}{|c|c|c|c|c|c|}
\hline \multirow{2}{*}{ Total moistures } & External moisture & & & & \\
\hline & Inherent moisture & & & & \\
\hline Ash & & & & & \\
\hline Volatile matter & & $\begin{array}{l}\frac{.0}{10} \\
\mathbb{0} \\
0\end{array}$ & & $\frac{\omega 0}{n}$ & $\begin{array}{l}8 \\
0 \\
0\end{array}$ \\
\hline Fixed carbon & & 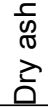 & 敢 & $\begin{array}{l}. \frac{\Phi}{2} \\
\frac{0}{2} \\
. \frac{1}{2}\end{array}$ & $\begin{array}{l}\frac{\mathrm{U}}{\mathrm{d}} \\
\frac{\mathrm{U}}{8} \\
\frac{0}{4}\end{array}$ \\
\hline
\end{tabular}

Figure 3. Components of biomass reporting to different bases

In converting some properties from one basis to another, the following general formula can be used [21]:

$$
P_{\text {wanted }}=P_{\text {given }} \cdot f_{c}
$$

where $P_{\text {wanted }}$ is the property based on a wanted basis, $P_{\text {given }}$ is the property based on a given basis, and $f_{c}$ is the conversion factor. Table 3 lists the conversion factors between different bases of analysis, where $M$ represents the moisture content, $A$ represents the ash content, the subscripts $\mathrm{ARB}, \mathrm{ADB}$ and $\mathrm{DB}$ represent the values related on as received basis, air dried basis and dry basis. 
Table 3. Conversion factors between different bases of analysis

\begin{tabular}{ccccc}
\hline \multirow{2}{*}{ Given } & \multicolumn{4}{c}{ Wanted } \\
\cline { 2 - 5 } As received basis & 1 & $\frac{1-M_{\mathrm{ADB}}}{1-M_{\mathrm{ARB}}}$ & $\frac{1}{1-M_{\mathrm{ARB}}}$ & $\frac{1}{1-M_{\mathrm{ARB}}-A_{\mathrm{ARB}}}$ \\
Air dried basis & $\frac{1-M_{\mathrm{ARB}}}{1-M_{\mathrm{ADB}}}$ & 1 & $\frac{1}{1-M_{\mathrm{ADB}}}$ & $\frac{1}{1-M_{\mathrm{ADB}}-A_{\mathrm{ADB}}}$ \\
Dry basis & $1-M_{\mathrm{ARB}}$ & $1-M_{\mathrm{ADB}}$ & 1 & $\frac{1}{1-A_{\mathrm{DB}}}$ \\
Dry ash free basis & $1-M_{\mathrm{ARB}}-A_{\mathrm{ARB}}$ & $1-M_{\mathrm{ADB}}-A_{\mathrm{ADB}}$ & $1-M_{\mathrm{DB}}$ & 1 \\
\hline
\end{tabular}

\section{Physical properties}

The physical properties of lignocellulosic biomass include particle size, density, flowability, grindability, moisture sorption and thermal properties.

\subsection{Particle size}

The shape and size of biomass feedstock particles affect the mixing and fluidization, surface area for heat and mass transfer and the flow behavior of biomass particles. Hence, feedstock with different shape and size can have different conversion efficiency and energy input requirement. The feedstock are usually pretreatment to meet the requirement of different thermochemical conversion technologies [22]. As shown in Ref. [23], the particle size is very relevant for the thermochemcial conversion technology selection process.

In general, lignocellulosic biomass is irregular in shape, which results in difficulties in accurate dimension measurements of length, width, and thickness [10]. The accurate characterization for biomass particle size and shape is essential for designing the handling, storage, and processing facilities. Aspect ratio, $A R$, is an important parameter for particle and it affects the heat transfer during thermal conversion of feedstock. It can be expressed as follows:

$$
A R=\frac{b}{l}
$$


where $A R$ is aspect ratio, $b$ is the width which is the minimum distance between two parallel lines tangential to the projected outline of the particle, $l$ is the length which is the maximum distance between two parallel lines perpendicular to the tangents for the width. According to Ref. [24], the aspect ratio of biomass particles affects the heat transfer during their thermal conversion.

Sieving analysis and imaging particle analysis are two major particle size characterization methods [10].

In sieving analysis, a set of sieves with different opening sizes and a suitable screen shaker are required. The sieves are arranged horizontally in a stack with gradually reduced opening size from top to bottom. The determination of the size distribution of particulate biomass feedstocks by sieving analysis can follow the American National Standards Institute / American Society of Agricultural Engineerings (ANSI/ASAE) standard S424.1 [25] or the British Standard / European Standard / International Organization for Standardization (BS EN ISO) standard 17827-1:2016 [26]. The sieve stack is placed in the shaker, which requires the sieve stack mounted on top of a shaker with fixed shaking time. The materials remained on each sieve are weighed after the shaking. The geometric mean diameter of the measured samples $d_{g m}$ can be calculated as follows:

$$
d_{g m}=\log ^{-1} \frac{\sum\left(M_{i} \cdot \log \sqrt{d_{i} \cdot d_{i-1}}\right)}{\sum M_{i}}
$$

where $d_{i}$ is the diagonal of screen apertures of the $i$ th screen, $d_{i-1}$ is the diagonal of screen apertures in the next larger screen (just above in the set), and $M_{i}$ is the mass on the $i$ th screen.

Figure 4 presents an example for the sieving analysis results of chopped switchgrass and sorghum residue (data adapted from Refs. [27, 28]). According to Equation (3), the geometric mean diameters of chopped switchgrass and sorghum residue are $7.80 \mathrm{~mm}$ and $0.70 \mathrm{~mm}$, respectively. 

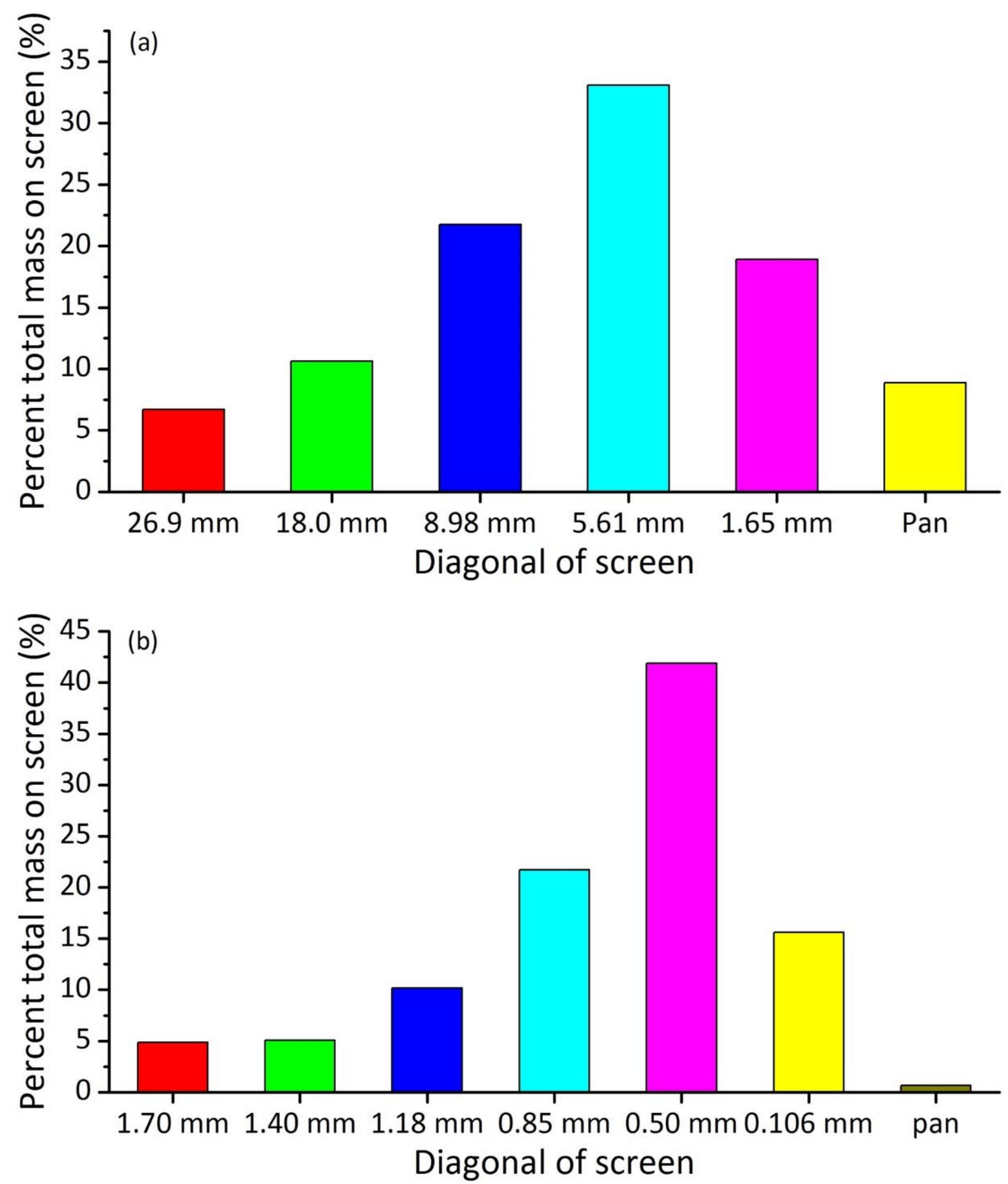

Figure 4. Particle size distribution of (a) chopped switchgrass and (b) sorghum residue (data adapted from Refs. [27, 28])

Digital imaging particle analysis can reveal particle size, particle shape and particle dimensions [29]. The deliberately separated particles are scattered on a transparent plastic sheet and the images of the pattern are scanned. The number, length,-width, and aspect ratio of 
particles can be obtained by analyzing the images.

In general, biomass feedstock should be comminuted to make it from its as received condition to the final particle size specification required by the end user [30]. The feedstock commination is dependent on many factors including biomass material properties and process variables of the grinding system [31]. In general, particle sizes of ground biomass have a lognormal distribution, which indicates that the number of smaller biomass particles are considerably greater than that of larger particles.

\subsection{Grindability}

Biomass pretreatment includes particle size reduction, which is related on another physical property: grindability. The grindability of a material is a measure of its resistance to grind. The lignocellulosic components of biomass, especially cellulose and lignin, are very fibrous and difficult to grind [32].

Standard grindability tests have been developed for coal [33] and petroleum coke [34], which use the Hardgrove Grindability Index (HGI) test [35]. Currently, there is no standard grindability test for biomass. Several studies used the HGI test for coal on biomass [36-41]. The HGI of a material can be determined empirically using a sample mill according to the following procedure [33]: 1) a small mass of prepared sample is filled into the sample mill; 2) after a standard number of rounds, the grinded material is sieved; 3) the quantity less than a specified size is recorded and converted into a HGI value. The lower the HGI, the harder and less grindable the material. Typical HGI values lie between 30 and 100 .

The above classical HGI method is inadequate for characterizing the grindabilities of biomass as it involves pregrinding to obtain a sample with a particle size in the range of $0.6-$ $1.2 \mathrm{~mm}$ prior to the HGI test [42]. And the grinding energy is not considered by the HGI method. Thus, an alternative Bond Work Index (BWI) method was proposed for the estimation of the grindability of biomass [43]. The BWI is defined as the calculated specific energy applied in reducing material of infinite particle size to $80 \%$ passing $100 \mu \mathrm{m}$. The higher the BWI value, the more energy is required to grind a material in a ball mill. The BWI test is widely used in the 
mining industry for determining the resistance of the material to ball milling and for estimating the energy consumption for grinding [44]. Williams et al. [43] obtained the BWI values of some biomass pellets, which ranged from 15 to $420 \mathrm{kWh} \mathrm{t}^{-1}$. The grindability of torrefied pellet is the best, and that of wood pellet is the worst.

The grindability of biomass can be greatly improved due to increased brittleness and a reduction of the cellulose fiber length through torrefaction $[39,45]$.

Grinding biomass is an energy-intensive process. Energy consumption for grinding depends on the initial and final biomass particle size, moisture content, material properties, mass feed rate and machine variables such as screen size and type of grinding equipment [46]. Mani et al. [47] correlated the grinder screen size and the energy requirement for a hammer mill. The results showed that the energy consumption for grinding biomass from a mean chop size of $7.15 \mathrm{~mm}$ to between 3.5 and $0.5 \mathrm{~mm}$ could be approximated by the following equation:

$$
E_{g}=5.31 * d_{p}^{2}-30.86 * d_{p}+55.45
$$

where $E_{g}$ is the energy consumption for grinding $\left(\mathrm{kWh} \mathrm{t}^{-1}\right)$, and $d_{p}$ is the particle size $(\mathrm{mm})$.

\subsection{Density}

Biomass can be characterized using two densities: the particle density and the bulk density [48].

\subsubsection{Particle density}

For a group of biomass particles, the particle density is the mass of all particles divided by the volume which the particles occupy excluding the pore space volume [10]:

$$
\rho_{p}=\frac{m_{p}}{V_{p}}
$$

where $\rho_{p}$ is the particle density, $m_{p}$ is the particle mass, and $V_{p}$ is the particle true volume. For biomass particles that cannot be defined geometrically, their true volume can be determined by the pressure difference with a known quantity of pressurized gas flowing from a reference 
volume into a cell containing biomass particles [10].

$$
V_{p}=V_{c}-V_{R}\left(\frac{P_{1}}{P_{2}}-1\right)
$$

where $V_{c}$ is the sample cell volume, $V_{R}$ is the reference volume, $P_{1}$ is the pressure after pressurizing the reference volume, and $P_{2}$ is the pressure after including $V_{c}$.

The particle density of biomass is usually used in the computational fluid dynamics simulation of biomass thermochemical conversion reactors [49].

\subsubsection{Bulk density}

The bulk density is the ratio of the mass of biomass particles to the total volume of biomass particles including the pore space volume between and within the biomass particles. It is a key physical property in designing the logistic system for biomass handling and transport. It depends on the biomass particle size and shape, moisture content, particle density, and surface characteristics [50].

The measurement of the bulk density of a biomass sample can be performed in accordance with the American Society for Testing and Materials (ASTM) standard E873 - 82 [51]. The standard involves pouring the biomass sample into a standard-size box $(305 \mathrm{~mm} \times 305 \mathrm{~mm} \times$ $305 \mathrm{~mm}$ ) from a height of $610 \mathrm{~mm}$. The excess material is removed by striking a straight edge across the top of the container. The net mass of the sample is obtained and the bulk density can be determined.

Bulk densities of different biomass feedstocks show extreme variation, from lows of 15 $200 \mathrm{~kg} \mathrm{~m}^{-3}$ for cereal grain straws to highs of $280-480 \mathrm{~kg} \mathrm{~m}^{-3}$ for hardwood chips [52]. Generally, the bulk density of lignocellulosic biomass is relatively low compared with the bulk density of coal (about $900 \mathrm{~kg} \mathrm{~m}^{-3}$ ) [53]. The bulk density of biomass is also dependent on the degree of fill tightness. Lam et al. [54] pointed out that the bulk density of switchgrass ranged from 50 to $264 \mathrm{~kg} \mathrm{~m}^{-3}$ for loose fill and from 68 to $325 \mathrm{~kg} \mathrm{~m}^{-3}$ for packed fill after tapping.

The pore spaces in bulk samples can be described by the porosity, which is defined by the following formula: 


$$
\varepsilon_{0}=1-\frac{\rho_{b}}{\rho_{p}}
$$

where $\varepsilon_{0}$ is the porosity of bulk biomass, $\rho_{b}$ is the bulk density, and $\rho_{p}$ is the particle density.

\subsection{Flowability}

The flow properties of biomass feedstocks play an important role in the transportation, storage, and handling [55]. Bridging of biomass particles usually occurs in the feeding subsystem of biomass conversion systems [56, 57]. Flowability, as a foremost flow property, is a measure of how well biomass flows from one point to another point [58].

Several parameters are commonly reported to characterize the flowability of biomass: the angle of repose, cohesion coefficient, compressibility index, and flow index [59].

The angle of repose is the steepest angle at which a heap of biomass particles can remain stable without slumping [60]. It can range from $0^{\circ}$ to $90^{\circ}$. There are numerous methods for measuring angle of repose, for example, the titling box method, the fixed funnel method, and the revolving cylinder method [61].

The fixed funnel method presented in the ASTM standard C144 [62] is introduced here. Sieved biomass particles are slowly poured through a funnel to form a cone. Stop pouring biomass particles when the pile reaches a predetermined height or the base a predetermined width. The angle of repose can be calculated:

$$
\phi=\tan ^{-1}\left(\frac{H}{R}\right)
$$

where $\phi$ is the angle of repose, $H$ and $R$ are the height and radius of the piling cone.

Different angles of repose correspond to different flowability grades. The flowability of biomass can be generally classified as high flowing, medium flowing, low flowing, cohesive, and very cohesive [10]. Mani [63] gave the flowability grades under different ranges of angle of repose (Table 4). 
Table 4. Classification of biomass flowability by angle of repose and flow index

\begin{tabular}{ccc}
\hline Angle of repose & Flow index & Flowability grade \\
\hline $55^{\circ}<\phi$ & FI $<1$ & Very cohesive \\
$45^{\circ}<\phi<55^{\circ}$ & $1<$ FI $<2$ & Cohesive \\
$38^{\circ}<\phi<45^{\circ}$ & $2<$ FI $<4$ & Low flowing \\
$30^{\circ}<\phi<38^{\circ}$ & $4<$ FI $<10$ & Medium flowing \\
$\phi<30^{\circ}$ & FI $>10$ & High flowing \\
\hline
\end{tabular}

The cohesion coefficient between the particles is a function of the diameter of the particles and the angle of repose [64]:

$$
C=\frac{1}{2} d\left(\sqrt{\cos ^{2} \phi+\frac{4 \sin \phi}{d}}-\cos \phi\right)
$$

where $C$ is the cohesion coefficient and $d$ is the diameter of the particles.

With certain consolidating pressure, the bulk density of biomass increases. Then the compressibility index of biomass can be obtained [65]:

$$
C_{b}=1-\frac{\rho_{b i}}{\rho_{b f}}
$$

where $C_{b}$ is the compressibility, $\rho_{b i}$ is the initial bulk density before consolidation, $\rho_{b f}$ is the final bulk density at the given consolidation pressure.

The shear tester can be used to quantify the flow behavior of biomass particles. The method is well-defined in the ASTM standard D6128-16 [66]. The unconfined yield stress $\left(\sigma_{c}\right)$ and the major consolidating stress $\left(\sigma_{1}\right)$ can be recorded. The flow function for biomass particles can be then obtained from the slope of the linear fit of $\sigma_{c}$ versus $\sigma_{1}$ plot. The inverse of the flow function is the flow index. Jenike [67] used the flow index to categorize the flowability of particles (Table 4).

\subsection{Moisture sorption}

The study on the moisture sorption of biomass is important for biomass harvest, handling, transport and storage. Therefore, proper drying and storage operations are required to preserve 
the quality of biomass feedstocks.

The Equilibrium Moisture Content (EMC) is a key parameter to characterize the water sorption behavior of biomass, and it is defined as the moisture content of a material in equilibrium in a particular environment with respect to temperature and relative humidity [68]. The EMC of biomass depends on its composition, porosity, microstructure and specific surface area [69]. There are static and dynamic methods to determine the equilibrium moisture content. The various relative humidities are obtained from saturated salt solution of acids of different concentrations in the static method and by mixing fully dried air and fully saturated air at required proportions in the dynamic method. The sample reaches equilibrium more rapidly with the dynamic method than with the static one.

Moisture sorption isotherm is usually used to describe the relationship between water content and equilibrium humidity at equilibrium [70]. For each humidity value, a sorption isotherm indicates the corresponding water content value at a given constant temperature [71]. Several equations have been proposed to describe the relationship between EMC, equilibrium humidity and temperature. They are shown in Table 5. 
Table 5. Equations for moisture sorption isotherm ${ }^{\text {a }}$

\begin{tabular}{cc}
\hline Names & Equations \\
\hline Henderson & $E M C=\left[\frac{\ln (1-E R H)}{-A T}\right]^{1 / B}$ \\
Modified Henderson & $E M C=\left[\frac{\ln (1-E R H)}{-A(T+C)}\right]^{1 / B}$ \\
Modified Chung-Pfost & $E M C=-\frac{1}{B}\left[\frac{\ln E R H(T+C)}{-A}\right]$ \\
Modified Halsey & $E M C=\left[\frac{-\exp (A+C T)}{\ln E R H}\right]^{1 / B}$ \\
Modified Oswin & $E M C=(A+C T)\left(\frac{E R H}{1-E R H}\right)^{1 / B}$ \\
Modified Guggenheim-Anderson-deBoer & $E M C=\frac{A \cdot B \cdot C \cdot E R H / T}{(1-B \cdot E R H)(1-B \cdot E R H+B \cdot C \cdot E R H / T)}$ \\
\hline
\end{tabular}

a $E M C$ is the equilibrium moisture content (wt.\%), $T$ is the temperature $\left({ }^{\circ} \mathrm{C}\right), E R H$ is the equilibrium relative humidity, $A, B$ and $C$ are temperature dependent constants.

The equilibrium moisture contents have been determined for various biomass feedstocks, such as Miscanthus [72], switchgrass [73], switchgrass pellets [74], corn stover [75, 76], energy sorghum [77], aspen [78] and energy cane [79]. The results showed that the adsorption process of biomass can be divided into two ranges: rapid adsorption and slow adsorption processes and EMC mainly depends on biomass type and environmental humidity.

\subsection{Thermal properties}

The thermal properties of biomass heavily influence its thermochemical conversion characteristics. This section describes two important thermal properties: thermal conductivity and specific heat. 


\subsubsection{Thermal conductivity}

When biomass is heated in thermochemical conversion processes, biomass particles are subject to heat conduction along and across their fiber, which in turn influences their thermochemical conversion behavior [80]. Mason et al. [81] developed a method for determining the thermal conductivities of biomass particles using a custom built test apparatus. They found that the thermal conductivities of dried wood pellets, miscanthus and willow are between 0.10 to $0.12 \mathrm{~W} \mathrm{~m}^{-1} \mathrm{~K}^{-1}$, while agricultural residues (such as wheat and rape straws) have a relatively low thermal conductivity value of $0.05 \mathrm{w} \mathrm{m}^{-1} \mathrm{~K}^{-1}$. Biomass is an anisotropic material. Its thermal conductivity depends on heating direction, moisture, porosity, density and temperature [82]. In Ref. [61], the following correlations between the thermal conductivity, density and moisture content were presented.

$$
K_{\text {eff }}\left(\mathrm{W} \mathrm{m}^{-1} \mathrm{~K}^{-1}\right)=\left\{\begin{array}{cc}
s g\left(0.2+0.004 M_{d}\right)+0.0238 & M_{d}>40 \% \\
s g\left(0.2+0.0055 M_{d}\right)+0.0238 & M_{d}<40 \%
\end{array}\right.
$$

where $K_{\text {eff }}$ is the thermal conductivity $\left(\mathrm{w} \mathrm{m}^{-1} \mathrm{~K}^{-1}\right), s g$ is the specific gravity, $M_{d}$ is the moisture percentage of biomass (\%).

\subsubsection{Specific heat}

Specific heat, which is an indication of the heat capacity of a material, is another important thermal property of biomass often required for thermodynamic calculations [83]. It depends on the moisture content of biomass and temperature.

From 0 to $106^{\circ} \mathrm{C}$, the specific heat of dried wood species can be expressed as [84]:

$$
C_{p \theta}=0.266+0.00116 \theta
$$

where $\theta$ is the temperature in ${ }^{\circ} \mathrm{C}, C_{p \theta}$ is the specific heat at the temperature $\theta\left(\mathrm{J} \mathrm{g}^{-1} \mathrm{~K}^{-1}\right)$.

Dupont et al. [83] correlated the relationship between the specific heat of dried agricultural residue samples with particle size below $200 \mu \mathrm{m}$ and temperature:

$$
c_{p T}=5.340 T-299
$$

where $T$ is the temperature in $\mathrm{K}, 313 \mathrm{~K} \leq T \leq 353 \mathrm{~K}, c_{p T}$ is the specific heat at the temperature 
$T\left(\mathrm{~J} \mathrm{~kg}^{-1} \mathrm{~K}^{-1}\right)$.

The effect of moisture on specific heat can be described by the following expression:

$$
C_{p}=M_{A R B} C_{w}+\left(1-M_{w e t}\right) C_{p \theta}
$$

where $M_{A R B}$ is the moisture content on as received basis, and $C_{w}$ is the specific heat of water.

\section{Chemical properties}

\subsection{Proximate analysis}

\subsubsection{General introduction}

Proximate analysis can give the amount of moisture, ash, volatile matter, and fixed carbon of the biomass sample.

Moisture content represents the quantity of water in biomass, expressed as a percentage of the material weight. It has a strong influence not only on harvest and preparation, but also on transport, storage, processing, and the resultant products [85]. The moisture in biomass can remain in external and inherent forms. The external moisture is that above the equilibrium moisture content, which will be introduced in Section 'Moisture Sorption'. It generally resides outside the cell walls. The inherent moisture is absorbed with the cell walls. Evaporation of moisture drains much of the deliverable energy consumed during the in thermochemical conversion processes, as the this part of energy can not be recovered [86].

Ash content represents the quantity of the solid residue left after the biomass sample is completely burned. The primary ingredients of biomass ash is the oxide form of silica, aluminum, iron, calcium, magnesium, titanium, sodium, and potassium [87]. Knowledge of the chemical properties and physical properties of the biomass ashes is helpful to predict the tendency to form deposits in the boiler components and composition of char produced in pyrolyser and gasifier [88].

The volatile matter of biomass is the condensable vapor and permanent gases (exclusive of water vapor) released from biomass when it is heated. According to Chouham and Sarma [89], higher volatile matter content implies increased amount of bio-oil production via pyrolysis. 
Its amount depends on the heating conditions including the heating rate, temperature, and residence time. For the determination of the volatile matter content of biomass's proximate analysis, the biomass sample is heated to a standard temperature and at a standard rate in a controlled environment.

Fixed carbon is the solid combustible residue that remains after biomass is heated and the volatile matter is expelled. Fixed carbon content in biomass is calculated value, which is determined from the following equation:

$$
F C=1-M-A-V M
$$

where $F C, M, A$ and $V M$ are the fixed carbon, moisture, ash and volatile matter contents in biomass on the same basis of analysis.

\subsubsection{ASTM standard method}

The moisture content of biomass is determined by the test approach given in the ASTM standard E1756 - 08 [90]. In the standard, a weighed sample is heated at $105 \pm 3{ }^{\circ} \mathrm{C}$ in a muffle for at least $3 \mathrm{~h}$ but not longer than $72 \mathrm{~h}$ and weighed after cooling. To ensure complete drying of the sample, the process is repeated until its weight remains unchanged.

The ash content of biomass can be measured by combusting the dried biomass sample in a muffle furnace at $575 \pm 25{ }^{\circ} \mathrm{C}$ for $3 \mathrm{~h}$, cooled and weighed, followed by a further $1 \mathrm{~h}$ at $575 \pm 25^{\circ} \mathrm{C}$ until sample mass varies by less than $0.3 \mathrm{mg}$ from previous weighing in accordance with the ASTM standard E1755 - 01 [91].

For the determination of the volatile matter content, the ASTM standard E872 - 82 [92] specifies that the dried biomass sample is put in a covered crucial so as to avoid contact with air during devolatilization and then the covered crucible is placed in a furnace at $950{ }^{\circ} \mathrm{C}$ and heated for $7 \mathrm{~min}$. Then, the crucible is taken out, cooled in a desiccator, and weighed. The weight loss due to devolatilization is the volatile matter content.

\subsubsection{Thermogravimetric analysis method}

For saving time and expense involved in proximate analysis using ASTM standards, Klass 
[93] proposed an alternative method using thermogravimetry. For proximate analysis of coal and coke, the ASTM standard D7582 - 15 [94] covers the determination of moisture, volatile matter, and ash by thermogravimetric analysis (TGA), which can give a continuous record of the weight loss of the sample during being heated. Several researchers also used the TGA method to perform the proximate analysis of biomass samples [95, 96].

The TGA method for proximate analysis is described as follows:

(1) Moisture determination. The weighted samples in crucibles without the covers are heated with a heating rate $\left(15\right.$ to $\left.50 \mathrm{~K} \mathrm{~min}^{-1}\right)$ from room temperature to $105{ }^{\circ} \mathrm{C}$, followed by a $105{ }^{\circ} \mathrm{C}$ isothermal hold for $3 \mathrm{~min}$ under inert atmosphere (nitrogen, argon or helium). The moisture content is calculated by the following formula:

$$
M=\frac{W-B}{W}
$$

where $W$ is the mass of the sample used, $B$ is the mass of the sample after drying in moisture test.

(2) Volatile matter determination. Then a heating ramp $\left(50-100 \mathrm{~K} \mathrm{~min}^{-1}\right)$ is programmed until $950{ }^{\circ} \mathrm{C}$, and a cooling process starts with a cooling rate $\left(-50--100 \mathrm{~K} \mathrm{~min}^{-1}\right)$ until $450{ }^{\circ} \mathrm{C}$. The volatile matter content is calculated by the following formula:

$$
V M=\frac{B-C}{W}
$$

where $C$ is the mass of the sample after heating in volatile matter test.

(3) Ash determination. The flow gas is changed to oxidizing gas (oxygen or air), then a heating ramp begins until $800{ }^{\circ} \mathrm{C}$, followed by an $800{ }^{\circ} \mathrm{C}$ isothermal hold for $3 \mathrm{~min}$. The ash content is calculated by the following formula:

$$
A=\frac{D}{W}
$$

where $D$ is the mass of the residue remaining after the ash test.

(4) Fixed carbon determination. The fixed carbon content is calculated according to Equation (15).

From the measured weight loss versus time graphs (Figure 5), the biomass sample's moisture, volatile matter, and ash contents can be determined. 

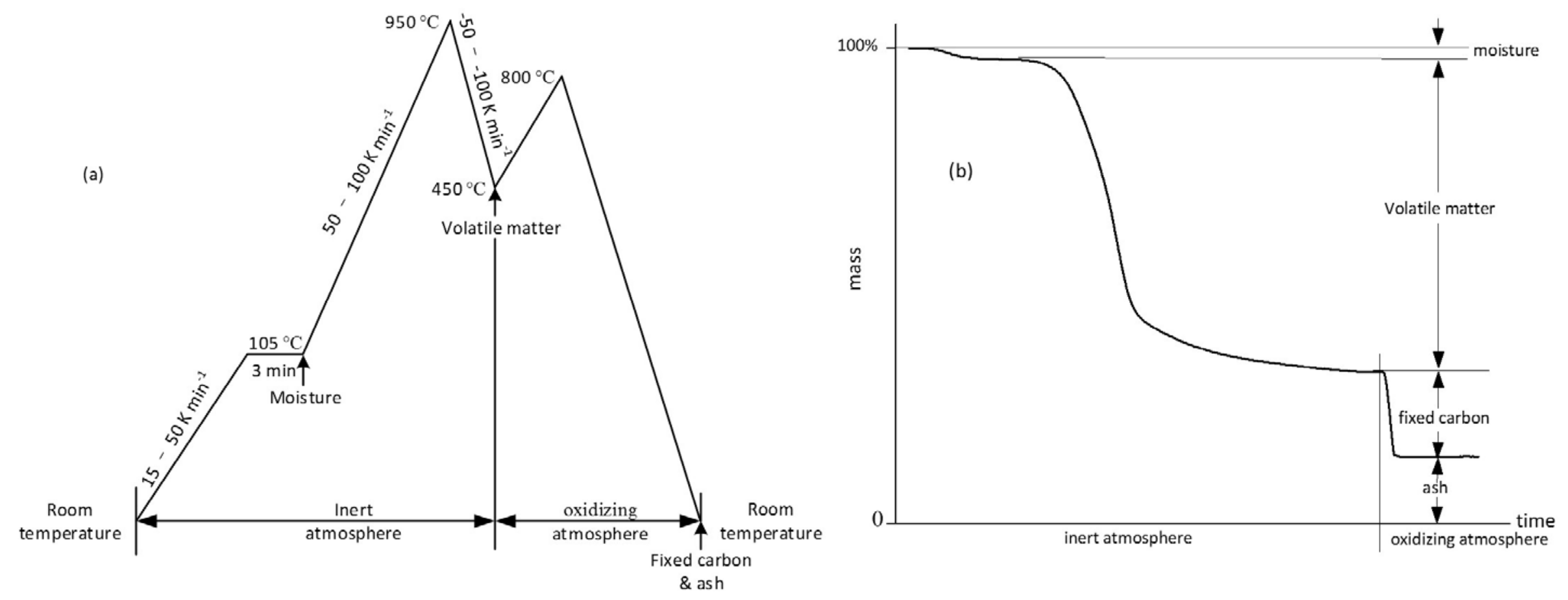

Figure 5. TGA method for proximate analysis of lignocellulosic biomass (a) temperature program, (b) thermogravimetric analysis curve 
Klass [93] compared the proximate analysis results of some biomass samples from the ASTM standard and TGA methods and obtained that the differences between the results from the ASTM standard and TGA methods were small.

\subsubsection{Typical results}

The proximate analysis results of biomass on dry basis can be illustrated using a ternary graph. It is a barycentric plots on three variables which sum to a constant and graphically depict the ratios of the three variables as positions in an equilateral triangle [24]. Figure 6 shows the proximate analysis results of typical biomass feedstocks on dry basis. These feedstocks include woody biomasses (pine, willow and poplar), crop straws (rice straw, cotton stalk, wheat straw and corn stalk), agro-industrial by-products (rice husk and sugarcane bagasse) and switchgrass. Figure 6 indicates that woody biomass feedstocks and sugarcane bagasse contain higher plenty of volatile matter than other biomass feedstocks. In addition, rice husk and straw contain higher ash content than other biomass feedstocks. 


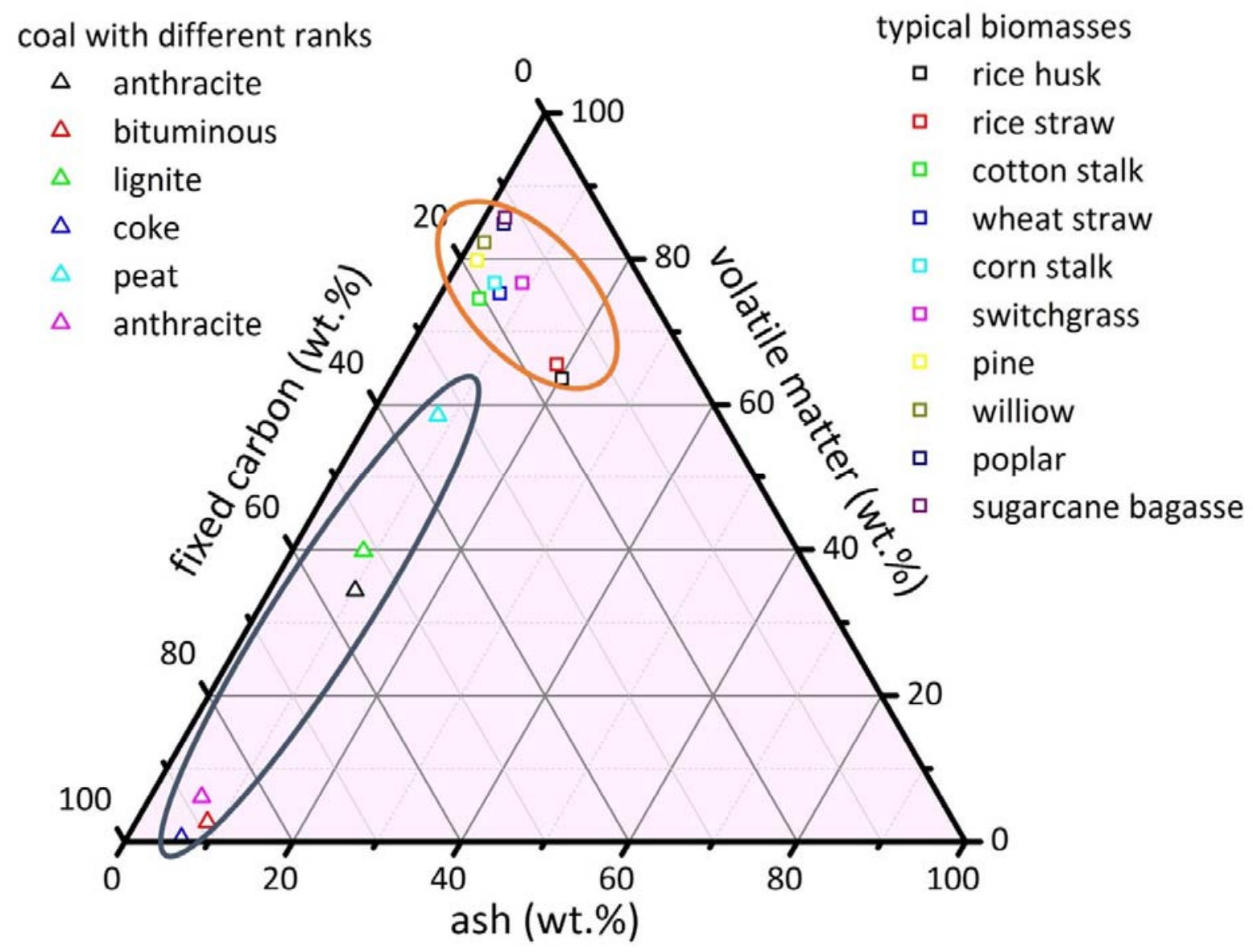

Figure 6. Proximate analysis results of typical biomass feedstocks and coal samples with different ranks on dry basis (data were taken from [97-100])

The proximate analysis results of some coal samples with different ranks on dry basis are also included in Figure 6. It can be observed that biomass has higher volatile matter content than coal,-whereas it has much lower fixed carbon content than coal. Therefore, a high amount of hydrocarbon species can be extracted from biomass simply via pyrolysis, whereas pyrolysis of coal generates mainly produces charcoal [101].

\subsection{Ultimate analysis}

The objective of ultimate analysis is to determine the contents of carbon, hydrogen, nitrogen, sulfur and oxygen. The ultimate analysis results are usually expressed on dry biomass basis or dry ash free basis.

Ultimate analysis is usually performed by using elemental analyzers through the 
combustion of a weighed biomass sample in a controlled atmosphere and subsequent analysis of its gas products [102]. In the combustion process, carbon is converted to $\mathrm{CO}_{2}$; hydrogen to $\mathrm{H}_{2} \mathrm{O}$; nitrogen to $\mathrm{NO}_{\mathrm{x}}$ and sulfur to $\mathrm{SO}_{2}$. The combustion products are swept out of the combustion chamber and passed over heated high purity copper, which can remove any oxygen and convert any $\mathrm{NO}_{\mathrm{x}}$ to $\mathrm{N}_{2}$. The contents of carbon, hydrogen, nitrogen, and sulfur can be determined through the detection of released $\mathrm{CO}_{2}, \mathrm{H}_{2} \mathrm{O}, \mathrm{N}_{2}$, and $\mathrm{SO}_{2}$ [31].

In general, the elemental composition results can be illustrated by van Krevelen diagramsorternary graphs, which cross-plot the hydrogen:carbon atomic ratios as a function of the oxygen:carbon atomic ratios of organic materials [103]. The major organic elemental analysis results of typical biomass feedstocks and coal samples with different ranks are shown in Figure 7. 

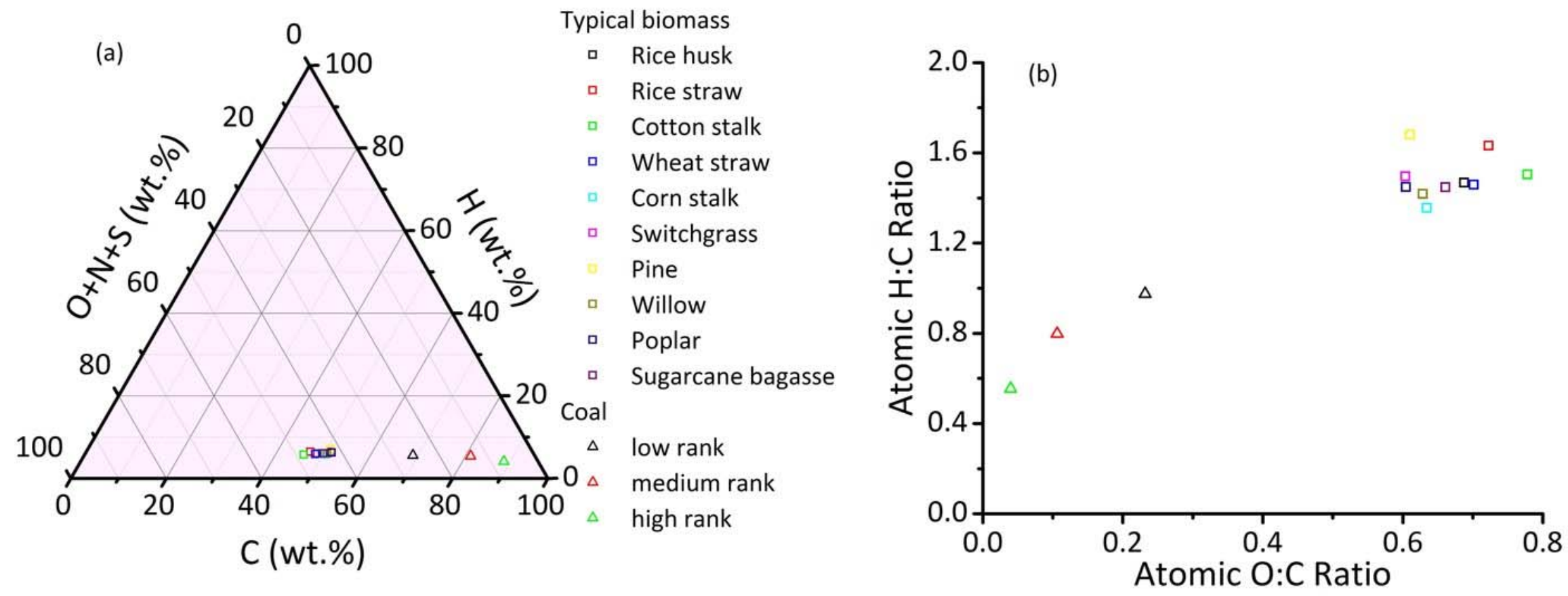

Figure 7. Ultimate analysis results of typical biomass feedstocks and coal samples with different ranks on dry ash free basis: (a) ternary diagram,

(b) van Krevelen diagram (data Refs. [97, 104-106]). 
Figure 7(a) shows that (1) the carbon content of typical biomass is around $45 \%$, while coal contains $60 \%$ or higher, (2) biomass contains a higher amount of oxygen than coal, and (3) the hydrogen contents of biomass and coal are in the range of $4.0-6.5 \%$. Figure $7(\mathrm{~b})$ indicates that biomass feedstocks with similar carbon and hydrogen contents are localized to distinct points in the van Krevelen diagram, while it is difficult to distinguish them in the ternary diagram. The van Krevelen diagram provides a simple tool for the demonstration of elemental compositional differences between samples of different nature (biomass versus coal) and between biomass feedstocks.

Mann et al. [79] proposed a CHO index to describe the oxidation state of organic carbon in organic materials:

$$
\mathrm{CHO} \text { index }=\frac{2[\mathrm{O}]-[\mathrm{H}]}{[\mathrm{C}]}
$$

where $[\mathrm{O}],[\mathrm{H}]$ and $[\mathrm{C}]$ are the mole fraction of oxygen, hydrogen and carbon. The $\mathrm{CHO}$ index can vary between -4 and +4 . Higher $\mathrm{CHO}$ index values can attribute to more oxidized compounds, while lower $\mathrm{CHO}$ index values denote reduced molecules of oxidized compounds. Figure 8 shows the CHO index values of typical biomass feedstocks (data adapted from Refs. $[97,104,106])$. It can be observed that the $\mathrm{CHO}$ index values of typical biomass feedstocks range from -0.50 to -0.05 , apart from cotton stalk. Cotton stalk has a $\mathrm{CHO}$ index value of around +0.05 , which indicates that the oxygen content of cotton stalk is relatively high while the hydrogen content is relatively low. 


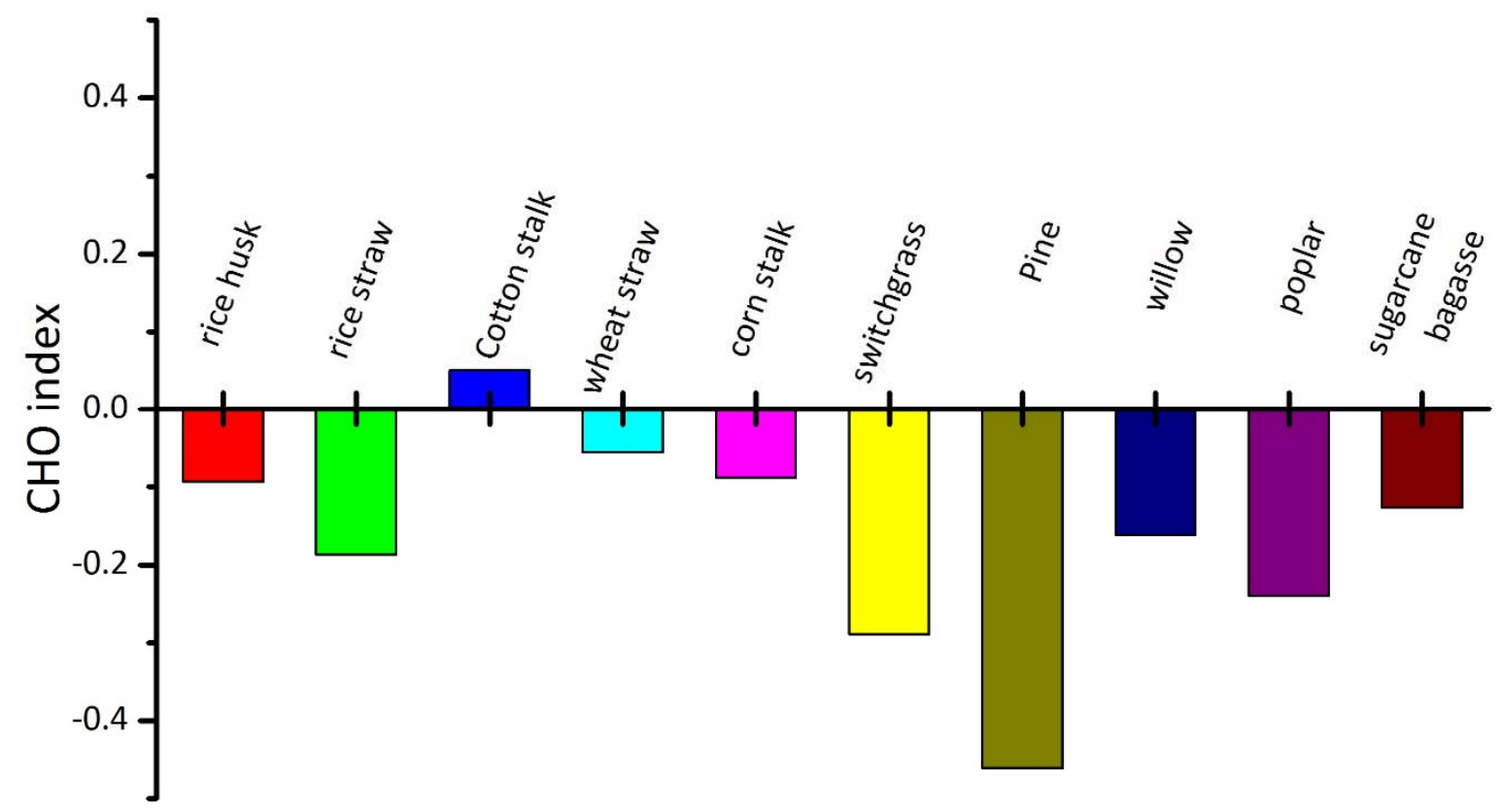

Figure 8. CHO index values of typical biomass feedstocks on dry ash free basis (data adapted from Refs. [97, 104, 106])

\subsection{Energy content}

The energy content of biomass is the amount of energy stored in a given unit of a biomass sample and is usually measured as the heat of combustion, which is the total energy released as heat when it undergoes complete combustion with oxygen under standard conditions [57].

Heating value (or calorific value) is commonly used as a measurement for the energy content. There are two heating value types frequently used, i.e., higher heating value (HHV) and lower heating value (LHV). The HHV is defined as the total amount of heat that is available in biomass including the latent heat of vaporization of water in the fuel and the reaction products [107]. The LHV does not include the latent heat of vaporization of water.

The standard method for the determination of the HHV of biomass uses an oxygen bomb calorimeter in accordance with the ASTM standard D5865 - 13 [41]. It burns a small mass of biomass in the presence of oxygen inside a sealed container and the heat released from combustion is measured.

When biomass is burnt, the hydrogen present in biomass produces steam. If the products 
of combustion are condensed, the latent heat of condensation of steam also counted in the measured heat [108]. Thus, the HHV and LHV of biomass on as received basis can be calculated based on the HHV of biomass on dry basis according to Equations (20) and (21) [109]:

$$
\begin{gathered}
H H V_{\mathrm{ARB}}=H H V_{\mathrm{DB}}\left(1-M_{\mathrm{ARB}}\right) \\
\mathrm{LHV}_{\mathrm{ARB}}=\mathrm{HHV}_{\mathrm{DB}}\left(1-M_{A R B}\right)-2.447 M_{A R B}-22.023 E C_{\mathrm{H}, \mathrm{DB}}\left(1-E C_{\mathrm{H}, \mathrm{DB}}\right)
\end{gathered}
$$

where $M_{\mathrm{ARB}}$ is the moisture content on as received basis, $E C_{\mathrm{H}, \mathrm{DB}}$ is $\mathrm{H}$ content on dry basis, $\mathrm{LHV}_{\mathrm{ARB}}$ is the LHV on as received basis $\left(\mathrm{MJ} \mathrm{kg}^{-1}\right)$ and $\mathrm{HHV}_{\mathrm{DB}}$ is the $\mathrm{HHV}$ on dry basis (MJ $\mathrm{kg}^{-1}$ ). Demirbas [110] gave the LHV values of poplar and corn stalk as a function of the moisture content and found that the LHVs of biomass samples decreased linearly with the increase of moisture contents.

The HHV of biomass on dry basis can be estimated from the contents of $\mathrm{C}, \mathrm{H}, \mathrm{S}, \mathrm{N}, \mathrm{O}$ and ash in biomass according to the following empirical equation from the International Energy Agency [23]:

$$
\begin{aligned}
H H V_{D B}= & 0.3491 E C_{\mathrm{C}, \mathrm{DB}}+1.1783 E C_{\mathrm{H} . \mathrm{DB}}+0.1005 E C_{\mathrm{S}, \mathrm{DB}}-0.0151 E C_{\mathrm{N}, \mathrm{DB}} \\
& -0.1034 E C_{\mathrm{O}, \mathrm{DB}}-0.0211 A_{\mathrm{DB}}
\end{aligned}
$$

The heating value of a lignocellulosic biomass type can vary significantly with the climate and soil conditions. Consequently, the HHV of a biomass type should be presented as a range rather than a fixed value [111]. The typical HHV ranges of some common lignocellulosic biomass types were reported in Ref. [112]. Woody biomasses have slightly higher values than herbaceous biomasses. The HHV values of most woody biomasses fall in the range of $18.5-$ $22.5 \mathrm{~kJ} \mathrm{~mol}^{-1}$, whereas the HHV values for most herbaceous biomasses are about $15.5-19.5 \mathrm{~kJ}$ $\mathrm{mol}^{-1}$.

\subsection{Compositional analysis}

\subsubsection{General introduction}

Lignocellulosic biomass is composed primarily of cellulose, hemicellulose, and lignin. Cellulose is a polymer of $\beta$-D-glucopyranose moieties linked via $\beta-(1,4)$ glycosidic bonds with 
well documented polymorphs [113]. Hemicellulose is a polymer consisting of short branched chains of sugars. Lignin is a complex, large molecular structure containing cross-linked phenolic polymers [114]. These components are associated with each other and vary-depending on the type of lignocellulosic biomass [17]. In biochemical or thermochemical conversion processes, the performances of cellulose, hemicellulose and lignin are different $[115,116]$. For example, compared to cellulose and hemicellulose, lignin has been considered a hindrance in cellulosic bioethanol production [117]. Accurate compositional analysis of lignocellulosic biomass enables evaluation of conversion yields and process economics, particularly in bioethanol conversion processes [118].

For compositional analysis, the lignocellulosic biomass samples should be prepared in a procedure in accordance with the ASTM standard E1757-01 [119], which can convert the samples into a uniform material suitable for analysis. The standard specifies a method for the preparation of samples with a specific particle size range and moisture content. The preparation procedure is described as follows: (1) dry the sample at $45 \pm 3{ }^{\circ} \mathrm{C}$ for 24 to $48 \mathrm{~h}$; (2) mill the dry sample to ensure the particles passing through a $2 \mathrm{~mm}$ screen; (3) sieve the milled sample; (4) choose $-20 /+80$ mesh fraction for further analysis.

There are three categories of compositional analysis methods: sulfuric acid hydrolysis methods [118, 120], near infrared spectroscopy (NIRS) methods [13], and kinetic analysis methods [121].

\subsubsection{Sulfuric acid hydrolysis method}

The most common methods are based on a two-step sulfuric acid hydrolysis, which has been used for over a century and modified for different objects and conditions [118]. Sluiter et al. [118] and Templeton et al. [120] reviewed the compositional analysis methods on the basis of sulfuric acid hydrolysis and their uncertainties. Many analogous versions of sulfuric acid hydrolysis methods have been reported [118]. The Laboratory Analytical Procedure (LAP) 'Determination of Structural Carbohydrates and Lignin in Biomass' published by the National Renewable Energy Laboratory (NREL) is the most updated version [122]. The procedure 
describes the quantification of carbohydrates and lignin, which is shown in Figure 9. This method begins with an ethanol extraction step. It can interfere with the accurate quantification of polysaccharide sugars, Klason lignin, and acid soluble lignin, which can be separated and quantified. The extracted components then undergoes typically a strong sulfuric acid hydrolysis step at room temperature and then a dilute sulfuric acid hydrolysis step at high temperature to break down to their monomeric forms, High Performance Anion Exchange Chromatography with Pulsed Amperometric Detection (HPAEC-PAD). The acid soluble lignin samples can be quantified using ultraviolet spectroscopy. The Klason lignin content can be gravimetrically obtained from the acid insoluble residue.

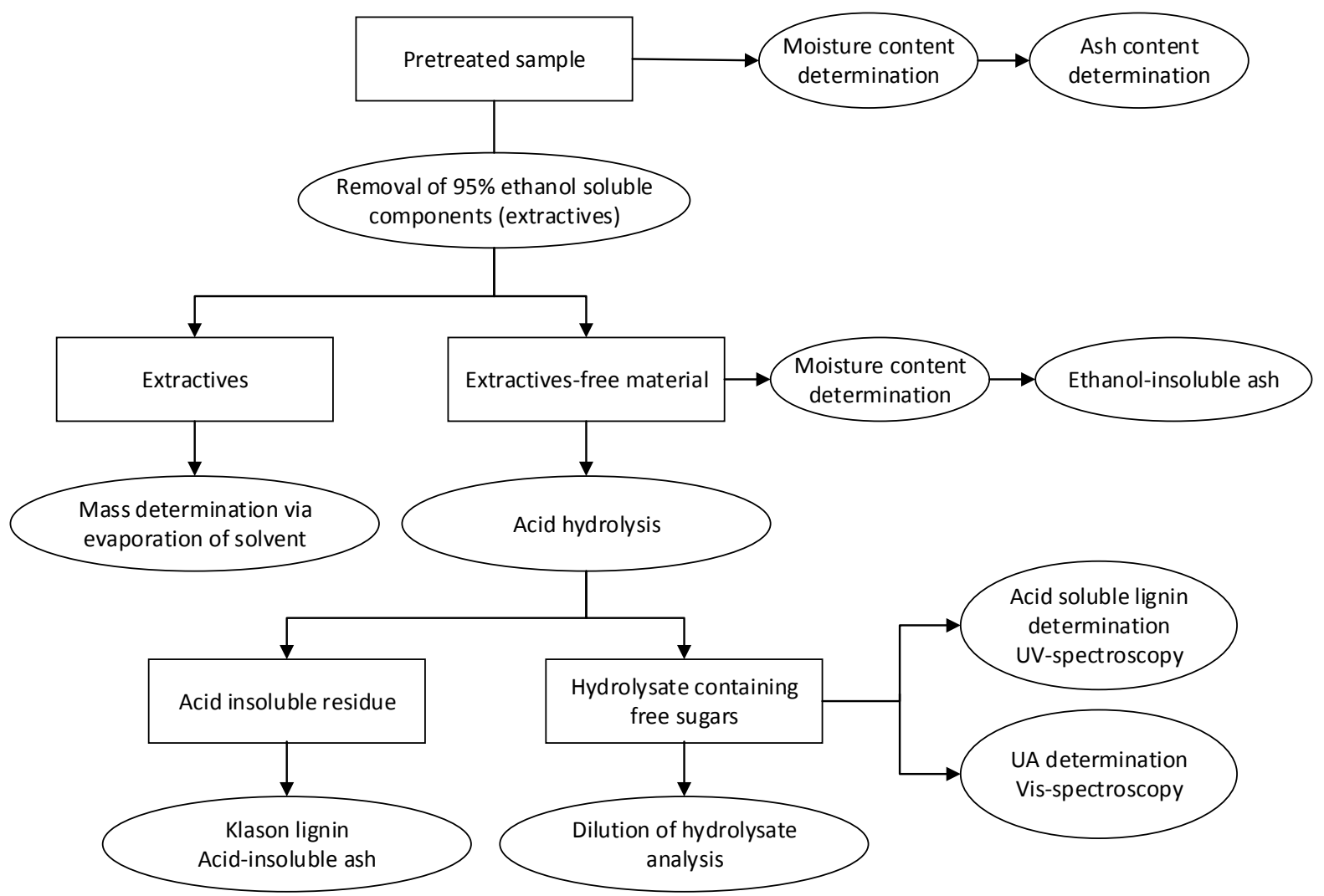

Figure 9. Flowchart of Laboratory Analytical Procedure (LAP) 'Determination of Structural Carbohydrates and Lignin in Biomass' by National Renewable Energy Laboratory (NREL)

\subsubsection{NIRS method}

The sulfuric acid hydrolysis methods can provide reliable results about biomass composition; however, they are labor-intensive, time-consuming and high-cost, and require pre- 
conditioning to remove extractives [123]. The NIRS methods can provide a reliable and lowcost solution for determination of biomass composition. The main advantages of the NIRS technique are (1) the procedure is relatively less complicated, (2) the analysis process is fast and precise, (3) no hazardous chemicals are used in analysis [13]. The spectral features can be used for biomass compositional analysis, as different functional groups in the structural components of biomass can correspond to different infrared spectrums. However, infrared spectra contains information about chemical bonds but does not provide compositional information; consequently, some statistical models which establish a relationship between spectra features and chemical bonds are required [13]. Principle component analysis (PCA), partial least squares (PLS), artificial neural networks (ANN), and support vector machines (SVM) are usually used for qualitative analysis [124]. After calibration, another external validation set of samples is prepared for validation to compare the predicted values from the calibration model and those from the reference method. Jin and Chen [125] successfully obtained a prediction of the total ash, insoluble ash, moisture, cellulose, hemicellulose, and Klason in a rice straw sample using NIRS.

\subsubsection{Kinetic method}

Carrier et al. [126] developed a kinetic method to calculate the contents of cellulose and hemicelluloses, using thermogravimetric analysis; however, the method cannot be-applied to determine lignin content of biomass. Cai et al. [121] presented different kinetic analysis method to determine the contents of cellulose, hemicellulose and lignin by using a distributed activation energy model: (1) The pyrolysis of lignocellulosic biomass is performed in a thermogravimetric analyzer under an inert atmosphere; (2) Three individual distributed activation energy models are used to describe the pyrolysis kinetic behaviors of cellulose, hemicellulose, and lignin,

$$
\begin{gathered}
\frac{\mathrm{d} \alpha}{\mathrm{d} T}=\sum_{j=1}^{3} c_{j} \frac{\mathrm{d} \alpha_{j}(T)}{\mathrm{d} T} \\
\frac{\mathrm{d} \alpha_{j}(T)}{\mathrm{d} T}=\frac{1}{\sqrt{2 \pi} \sigma_{j}} \int_{0}^{\infty} \frac{k_{0, j}}{\beta} \exp \left[-\frac{E}{R T}-\frac{k_{0, j}}{\beta} \int_{0}^{T} \exp \left(-\frac{E}{R T}\right) \mathrm{d} T-\frac{\left(E-E_{0, j}\right)^{2}}{2 \sigma_{j}^{2}}\right] \mathrm{d} E
\end{gathered}
$$


In the above equations, $\alpha$ is the conversion degree of lignocellulosic biomass, $T$ is the absolute temperature, $\alpha_{j}(T)(j=1,2,3)$ are the conversion degree of cellulose, hemicellulose, and lignin, respectively, $R$ is the universal gas constant, $E_{0}$ is the mean value of the activation energy distribution, $k_{0}$ is the frequency factor, $c_{j}(j=1,2,3)$ are the fractions of cellulose, hemicellulose, and lignin; (3) A pattern search method is used to determine-the parameters of the distributed activation energy model by minimizing the sum of squared residuals between the experimental data and the calculated data from the distributed activation energy model; (4) The contents of cellulose, hemicellulose and lignin can be calculated based on the parameter $c_{j}$ values.

\subsubsection{Typical results}

The relative contents of cellulose and lignin are key factors to identify the suitability of lignocellulosic biomass for processing, particularly the biochemical conversion processes [127]. The biodegradation of cellulose is greater than that of lignin; therefore, the overall conversion of biomass with a higher content of cellulose is greater than biomass with a higher content of lignin [128]. Forest and agricultural residues are suitable for combustion, gasification, and pyrolysis, while other feedstocks such as sugar crops are suitable to bioethanol fermentation.

Table 6 gives the contents of cellulose, hemicellulose and lignin of some common lignocellulosic biomass feedstocks. 
Table 6. Compositional analysis results of typical lignocellulosic biomasses (data adapted from Refs. $[17,129,130])$

\begin{tabular}{cccc}
\hline Biomass & Cellulose / wt.\% & Hemicellulose / wt.\% & Lignin / wt.\% \\
\hline Hardwood (Poplar) & $50.8-53.3$ & $26.2-28.7$ & $15.5-16.3$ \\
Softwood (Pine) & $45.0-50.0$ & $25.0-35.0$ & $25.0-35.0$ \\
Wheat straw & $35.0-39.0$ & $23.0-30.0$ & $12.0-16.0$ \\
Corn Cob & $33.7-41.2$ & $31.9-36.0$ & $6.1-15.9$ \\
Corn Stalk & $35.0-39.6$ & $16.8-35.0$ & $7.0-18.4$ \\
Rice Straw & $29.2-34.7$ & $23.0-25.9$ & $17.0-19.0$ \\
Rice Husks & $28.7-35.6$ & $12.0-29.3$ & $15.4-20.0$ \\
Sugarcane Bagasse & $25.0-45.0$ & $28.0-32.0$ & $15.0-25.0$ \\
Sorghum Straw & $32.0-35.0$ & $24.0-27.0$ & $15.0-21.0$ \\
Barley Straw & $36.0-43.0$ & $24.0-33.0$ & $6.3-9.8$ \\
Grasses & $25.0-40.0$ & $25.0-50.0$ & $10.0-30.0$ \\
Switchgrass & $35.0-40.0$ & $25.0-30.0$ & $15.0-20.0$ \\
\hline
\end{tabular}

\section{Summaries}

Lignocellulosic biomass can be converted into bioenergy, biofuels and biochemical by various routes. The physicochemical properties of biomass are key parameters to understand prior to designing any thermochemical or biochemical processing method as they significantly influence the process conversion performance and associated supply chain network for material handing and transport. However, the profound understanding of the physicochemical properties of lignocellulosic biomass and the analytical characterization methods for these properties are required. All properties and their characterization techniques reviewed in this paper are listed in Table 7. The summaries of this review are given below.

- Sieving analysis is a fast and easy approach to measure particle size, while imaging particle analysis can be used if particle shape and dimensions are required.

- Bond work index is an approach to measure grindability as grinding energy is considered.

- Bulk density of particle is measured following the ASTM standard E873-82, and particle density is measured using the pressurized gas flowing method.

- Flowability is quantified as angle of response and flow index, which can be measured 
according to the ASTM standards C144-00 and D6128-16, respectively.

- Dynamic method is a fast approach to measure sorption compared to static method.

- To measure proximate analysis properties (e.g. moisture, ash, volatile and fixed carbon contents), the researcher can either choose a fast and easy thermogravimetric analysis method while sacrificing some precision, or select a precise ASTM standard approach while consuming long time.

- Elemental analyzer is commonly used to perform ultimate analysis (e.g. C, H, N, S and O contents) of biomass.

- To measure energy content (e.g. higher or lower heating values), the researcher can either choose a fast and empirical calculation method while elemental composition is required, or select a precise oxygen bomb calorimeter method.

- To measure chemical composition (e.g. cellulose, hemicellulose and lignin contents), the researcher can choose (1) a fast and empirical kinetic method while complex calculation is required, or (2) a fast and precise near infrared spectroscopy method while some statistical models are required, or (3) a precise sulfuric acid hydrolysis method while the disadvantages (e.g. labor-intensive and time-consuming) exits. 
Table 7. Summary of physicochemical properties of lignocellulosic biomass and their analytical characterization methods

\begin{tabular}{|c|c|c|c|}
\hline Property type / Method & Property & Standard or procedure & Advantages and disadvantages \\
\hline \multicolumn{4}{|l|}{ Particle size } \\
\hline \multicolumn{4}{|l|}{ Sieving analysis } \\
\hline & & & Advantages: fast and easy \\
\hline & Particle size distribution & ANSI/ASAE S424.1 & $\begin{array}{l}\text { Disadvantages: Only particle size distribution can be } \\
\text { obtained. }\end{array}$ \\
\hline \multicolumn{4}{|l|}{$\begin{array}{l}\text { Imaging particle } \\
\text { analysis }\end{array}$} \\
\hline & $\begin{array}{l}\text { Particle size, particle shape, and } \\
\text { particle dimensions }\end{array}$ & $\begin{array}{l}\text { Operating procedure of electron } \\
\text { microscopy }\end{array}$ & $\begin{array}{l}\text { Advantages: Particle size, particle shape, and particle } \\
\text { dimensions can be obtained. }\end{array}$ \\
\hline \multicolumn{4}{|l|}{ Grindability } \\
\hline & Hardgrove Grindability Index & ASTM D409/D409M-16 & Disadvantages: the method is for coal. \\
\hline & Bond Work Index & Bond work index method & Advantages: Grinding energy is considered. \\
\hline \multicolumn{4}{|l|}{ Density } \\
\hline & Bulk density & ASTM E873 - 82 & \\
\hline & Particle density & pressurized gas flowing method & \\
\hline \multicolumn{4}{|l|}{ Flowability } \\
\hline & Angle of repose & ASTM C144-00 & \\
\hline & Flow index & ASTM D6128 - 16 & \\
\hline \multicolumn{4}{|l|}{ Moisture sorption } \\
\hline \multicolumn{4}{|l|}{ Static method } \\
\hline & Equilibrium moisture content & & $\begin{array}{l}\text { The equilibrium criterion is difficult to define. The } \\
\text { equilibrium delay is very long. }\end{array}$ \\
\hline \multicolumn{4}{|l|}{ Dynamic method } \\
\hline & Equilibrium moisture content & & $\begin{array}{l}\text { Fast. The sorption isotherms between the ambient } \\
\text { temperature and } 95^{\circ} \mathrm{C} .\end{array}$ \\
\hline \multicolumn{4}{|c|}{ Proximate analysis properties } \\
\hline \multicolumn{4}{|c|}{$\begin{array}{l}\text { ASTM standard } \\
\text { method }\end{array}$} \\
\hline & Moisture content & ASTM standard E1756 - 08 & Advantages: precision \\
\hline & Ash content & ASTM standard E1755 - 01 & Disadvantages: time consuming, complex \\
\hline & Volatile matter content & $\begin{array}{l}\text { ASTM standard E872 - } 82 \\
37\end{array}$ & \\
\hline
\end{tabular}


Thermochemical

analysis method

Moisture content

Ash content

Volatile matter content

Fixed carbon content

Elemental composition

$$
\begin{aligned}
& \mathrm{C} \\
& \mathrm{H} \\
& \mathrm{N}
\end{aligned}
$$

$\mathrm{S}$

Energy content

Oxygen bomb

calorimeter method

Calculation method

Higher heating value

Lower heating value

Higher heating value

Chemical composition

Sulfuric acid

hydrolysis method

\section{Cellulose}

Hemicellulose

Lignin
Operating procedure of elemental

analyzer

ASTM D5865 - 13

Calculated from elemental composition

ASTM E1758 - 01

NREL, LAP
Advantages: Fast and easy

Disadvantages: empirical

Near infrared

spectroscopy method 


\section{Cellulose}

Hemicellulose

Lignin

Kinetic method

Cellulose

Hemicellulose

Lignin

Advantages: the sample preparation is simple, the analysis process is fast and precise, no hazardous chemical is used during analysis.

Disadvantages: some statistical models which establish a

relationship between spectra features and chemical

bonds are required.

perating procedure of near

infrared spectroscopy

Thermogravimetric analysis and

kinetic calculation
Advantages: fast

Disadvantages: empirical, complex calculation 


\section{Acknowledgements}

Financial support from the International Research Staff Exchange Scheme (IRSES) ECOFUEL Program (FP7-PEOPLE-2009-IRSES Grant 246772) is greatly acknowledged. Ronghou Liu appreciated the financial support from National Natural Science Foundation of China (51376121). Xi Yu and Anthony V. Bridgwater gratefully acknowledge the research grant from EPSRC (EP/M01343X/1). The authors appreciate Mr. Wenfei Cai, a Ph.D. candidate from Shanghai Jiao Tong University for his help in the graphical abstract.

\section{References}

[1] Sanna A. Advanced biofuels from thermochemical processing of sustainable biomass in Europe. BioEnergy Research. 2014;7:36-47.

[2] International Energy Agency, Key World Energy Statistics 2015. Retrieved at https://www.iea.org/publications/freepublications/publication/KeyWorld_Statistics_2015.pdf, 9th September 2016.

[3] Nanda S, Kozinski JA, Dalai AK. Biomass-an overview on classification, composition and characterization. Biomass Processing, Conversion and Biorefinery2013. p. 1-35.

[4] Collard F-X, Blin J. A review on pyrolysis of biomass constituents: Mechanisms and composition of the products obtained from the conversion of cellulose, hemicelluloses and lignin. Renewable and Sustainable Energy Reviews. 2014;38:594-608.

[5] Vertes AA, Qureshi N, Yukawa H, Blaschek HP. Biomass to Biofuels: Strategies for Global Industries: Wiley; 2011.

[6] Lynd LR, Sow M, Chimphango AF, Cortez LA, Cruz CHB, Elmissiry M, et al. Bioenergy and African transformation. Biotechnology for Biofuels. 2015;8:1.

[7] Goyal H, Seal D, Saxena R. Bio-fuels from thermochemical conversion of renewable resources: a review. Renewable and Sustainable Energy Reviews. 2008;12:504-17.

[8] Brethauer S, Studer MH. Biochemical conversion processes of lignocellulosic biomass to fuels and chemicals - A review. Chimia. 2015;69:572-81. 
[9] Yue D, You F, Snyder SW. Biomass-to-bioenergy and biofuel supply chain optimization: overview, key issues and challenges. Computers \& Chemical Engineering. 2014;66:36-56.

[10] Lam PS, Sokhansanj S. Engineering Properties of Biomass. In: Shastri Y, Hansen A, Rodríguez L, Ting KC, editors. Engineering and Science of Biomass Feedstock Production and Provision. New York, NY: Springer New York; 2014. p. 17-35.

[11] Kan T, Strezov V, Evans TJ. Lignocellulosic biomass pyrolysis: A review of product properties and effects of pyrolysis parameters. Renewable and Sustainable Energy Reviews. 2016;57:1126-40.

[12] Richter F, Fricke T, Wachendorf M. Utilization of semi - natural grassland through integrated generation of solid fuel and biogas from biomass. III. Effects of hydrothermal conditioning and mechanical dehydration on solid fuel properties and on energy and greenhouse gas balances. Grass and Forage Science. 2010;65:185-99.

[13] Xu F, Yu J, Tesso T, Dowell F, Wang D. Qualitative and quantitative analysis of lignocellulosic biomass using infrared techniques: a mini-review. Applied Energy. 2013;104:801-9.

[14] Lin F, Waters CL, Mallinson RG, Lobban LL, Bartley LE. Relationships between biomass composition and liquid products formed via pyrolysis. Frontiers in Energy Research. 2015;3.

[15] Räisänen T, Athanassiadis D. Basic chemical composition of the biomass components of pine, spruce and birch. 2013:http://www.biofuelregion.se/UserFiles/file/Forest\%20Refine/1_2_IS_2013-0131_Basic_chemical_composition.pdf.

[16] Arnoult S, Brancourt-Hulmel M. A Review on miscanthus biomass production and composition for bioenergy use: genotypic and environmental variability and implications for breeding. BioEnergy Research. 2015;8:502-26.

[17] Isikgor FH, Becer CR. Lignocellulosic biomass: a sustainable platform for the production of bio-based chemicals and polymers. Polymer Chemistry. 2015;6:4497-559.

[18] Vassilev SV, Baxter D, Andersen LK, Vassileva CG. An overview of the chemical composition of biomass. Fuel. 2010;89:913-33.

[19] Vassilev SV, Vassileva CG, Vassilev VS. Advantages and disadvantages of composition and properties of biomass in comparison with coal: An overview. Fuel. 2015;158:330-50. 
[20] Dahlquist E. Technologies for Converting Biomass to Useful Energy: Combustion, Gasification, Pyrolysis, Torrefaction and Fermentation: CRC Press; 2013.

[21] Riley JT. Routine Coal and Coke Analysis: Collection, Interpretation, and Use of Analytical Data. West Conshohocken, PA: ASTM International; 2007.

[22] Vidal BC, Dien BS, Ting KC, Singh V. Influence of feedstock particle size on lignocellulose conversion-A review. Applied Biochemistry and Biotechnology. 2011;164:1405-21.

[23] Van Loo S, Koppejan J. The Handbook of Biomass Combustion and Co-firing: Earthscan; 2008.

[24] Gera D, Mathur MP, Freeman MC, Robinson A. Effect of large aspect ratio of biomass particles on carbon burnout in a utility boiler. Energy \& Fuels. 2002;16:1523-32.

[25] ANSI/ASAE S424.1, Method of Determining and Expressing Particle Size of Chopped Forage Materials by Screening. St. Joseph, Michigan: American Society of Agricultural and Biological Engineers; 1992.

[26] BS EN ISO 17827-1:2016, Solid biofuels. Determination of particle size distribution for uncompressed fuels. Oscillating screen method using sieves with apertures of 3,15 $\mathrm{mm}$ and above. Geneva, Switzerland: International Organization for Standardization; 2016.

[27] Yang Y. Image and sieve analysis of biomass particle sizes and separation after size reduction: University of Tennessee - Knoxville; 2007.

[28] Wang L, Weller CL, Hwang KT. Extraction of lipids from grain sorghum DDG. Transactions of the American Society of Agricultural Engineers. 2005;48:1883-8.

[29] Yang WC. Handbook of Fluidization and Fluid-Particle Systems: Taylor \& Francis; 2003. [30] Holm-Nielsen J, Ehimen EA. Biomass Supply Chains for Bioenergy and Biorefining: Elsevier Science; 2016.

[31] de Jong W, van Ommen JR. Biomass as a Sustainable Energy Source for the Future: Fundamentals of Conversion Processes: Wiley; 2014.

[32] Capareda S. Introduction to Biomass Energy Conversions: CRC Press; 2013.

[33] ASTM D409/D409M-12e1, Standard Test Method for Grindability of Coal by the Hardgrove-Machine Method. West Conshohocken, PA: ASTM International; 2012.

[34] ASTM D5003-06a, Standard Test Method for Hardgrove Grindability Index (HGI) of 
Petroleum Coke. West Conshohocken, PA: ASTM International; 2011.

[35] ASTM D409/D409M-16, Standard Test Method for Grindability of Coal by the Hardgrove-Machine Method. West Conshohocken, PA: ASTM International; 2016.

[36] Gil MV, García R, Pevida C, Rubiera F. Grindability and combustion behavior of coal and torrefied biomass blends. Bioresource Technology. 2015;191:205-12.

[37] Commandré JM, Leboeuf A. Volatile yields and solid grindability after torrefaction of various biomass types. Environmental Progress and Sustainable Energy. 2015;34:1180-6.

[38] Arias B, Pevida C, Fermoso J, Plaza MG, Rubiera F, Pis J. Influence of torrefaction on the grindability and reactivity of woody biomass. Fuel Processing Technology. 2008;89:169-75.

[39] Phanphanich M, Mani S. Impact of torrefaction on the grindability and fuel characteristics of forest biomass. Bioresource Technology. 2011;102:1246-53.

[40] Bridgeman T, Jones J, Williams A, Waldron D. An investigation of the grindability of two torrefied energy crops. Fuel. 2010;89:3911-8.

[41] Ohliger A, Förster M, Kneer R. Torrefaction of beechwood: A parametric study including heat of reaction and grindability. Fuel. 2013;104:607-13.

[42] van Swaaij WPM, Kersten SRA, Palz W. Biomass Power for the World: Pan Stanford Publishing; 2015.

[43] Williams O, Eastwick C, Kingman S, Giddings D, Lormor S, Lester E. Investigation into the applicability of Bond Work Index (BWI) and Hardgrove Grindability Index (HGI) tests for several biomasses compared to Colombian La Loma coal. Fuel. 2015;158:379-87.

[44] Ahmadi R, Shahsavari S. Procedure for determination of ball Bond work index in the commercial operations. Minerals Engineering. 2009;22:104-6.

[45] Van der Stelt M, Gerhauser H, Kiel J, Ptasinski K. Biomass upgrading by torrefaction for the production of biofuels: A review. Biomass and Bioenergy. 2011;35:3748-62.

[46] Oginni OJ. Contribution of particle size and moisture content to flowability of fractionated ground loblolly pine: Auburn University; 2014.

[47] Mani S, Tabil LG, Sokhansanj S. Grinding performance and physical properties of wheat and barley straws, corn stover and switchgrass. Biomass and Bioenergy. 2004;27:339-52.

[48] Wang L. Sustainable Bioenergy Production: Taylor \& Francis; 2014.

[49] Xue Q, Fox RO. Computational modeling of biomass thermochemical conversion in 43 
fluidized beds: particle density variation and size distribution. Industrial \& Engineering Chemistry Research. 2014;54:4084-94.

[50] Bhagwanrao SV, Singaravelu M. Bulk density of biomass and particle density of their briquettes. International Journal of Agricultural Engineering. 2014;7:221-4.

[51] ASTM E873 - 82, Standard Test Method for Bulk Density of Densified Particulate Biomass Fuels. West Conshohocken, PA: ASTM International; 2006.

[52] Cheng J. Biomass to Renewable Energy Processes: CRC Press; 2009.

[53] Jose S, Bhaskar T. Biomass and Biofuels: Advanced Biorefineries for Sustainable Production and Distribution: CRC Press; 2015.

[54] Lam PS, Sokhansanj S, Bi X, Mani S, Lim CJ, Womac AR, et al. Physical characterization of wet and dry wheat straw and switchgrass - Bulk and specific density. ASABE Meeting. Minneapolis Convention Center, Minneapolis, Minnesota, USA2007. p. Paper Number: 076058. [55] Miao Z, Grift TE, Hansen AC, Ting K. Flow performance of ground biomass in a commercial auger. Powder Technology. 2014;267:354-61.

[56] Ueki Y, Torigoe T, Ono H, Yoshiie R, Kihedu JH, Naruse I. Gasification characteristics of woody biomass in the packed bed reactor. Proceedings of the Combustion Institute. 2011;33:1795-800.

[57] Dahlquist E. Biomass as Energy Source: Resources, Systems and Applications: CRC Press; 2013.

[58] Miccio F, Silvestri N, Barletta D, Poletto M. Characterization of woody biomass flowability. Chemical Engineering Transactions. 2011;24:643-8.

[59] Lumay G, Boschini F, Traina K, Bontempi S, Remy J-C, Cloots R, et al. Measuring the flowing properties of powders and grains. Powder Technology. 2012;224:19-27.

[60] Pascale CR. Comparison of methods for the measurement of the angle of repose of granular materials. Geotechnical Testing Journal. 2014;37:1-5.

[61] Kitani O, Hall CW. Biomass Handbook: Gordon and Breach Science Publishers; 1989.

[62] ASTM C144-00, Standard Test Method for Measuring the Angle of Repose of FreeFlowing Mold Powders. West Conshohocken, PA: ASTM International; 2000.

[63] Sudhagar M. Fuel and bulk flow properties of coal and torrefied wood mixtures for cofiring applications. 2015 TAPPI - International Bioenergy \& Bioproducts Conference. Atlanta, 
GA2015.

[64] Szalay A, Kelemen A, Pintye-Hódi K. The influence of the cohesion coefficient (C) on the flowability of different sorbitol types. Chemical Engineering Research and Design. 2015;93:349-54.

[65] Fasina OO. Flow Properties of Biomass Feedstocks. 2006 ASAE Annual Meeting: American Society of Agricultural and Biological Engineers; 2006. p. 1.

[66] ASTM D6128-16, Standard Test Method for Shear Testing of Bulk Solids Using the Jenike Shear Tester. West Conshohocken, PA: ASTM International; 2016.

[67] Jenike AW. Storage and flow of solids, bulletin no. 123. Bulletin of the University of Utah. $1964 ; 53$.

[68] Bridgwater AV, Boocock DGB. Developments in Thermochemical Biomass Conversion: Volume 1: Springer Netherlands; 2013.

[69] Lin G, Yang H, Wang X, Mei Y, Li P, Shao J, et al. The moisture sorption characteristics and modelling of agricultural biomass. Biosystems Engineering. 2016;150:191-200.

[70] Labuza TP. Moisture Sorption: Practical Aspects of Isotherm Measurement and Use: American Association of Cereal Chemists; 1984.

[71] Kaur M. Medical Foods from Natural Sources: Springer New York; 2008.

[72] Arabhosseini A, Huisman W, Müller J. Modeling of the equilibrium moisture content (EMC) of Miscanthus (Miscanthus× giganteus). Biomass and Bioenergy. 2010;34:411-6.

[73] Godbolt C, Danao M-GC, Eckhoff SR. Modeling of the equilibrium moisture content (EMC) of switchgrass. Transactions of the ASABE. 2013;56:1495-501.

[74] Colley Z, Fasina O, Bransby D, Lee Y. Moisture effect on the physical characteristics of switchgrass pellets. Transactions of the ASABE. 2006;49:1845-51.

[75] Igathinathane C, Womac A, Sokhansanj S, Pordesimo L. Sorption equilibrium moisture characteristics of selected corn stover components. Transactions of the ASAE. 2005;48:144960 .

[76] Igathinathane C, Pordesimo L, Womac A, Sokhansanj S. Hygroscopic moisture sorption kinetics modeling of corn stover and its fractions. Applied Engineering in Agriculture. 2009;25:65-73.

[77] Bonner IJ, Kenney KL. Moisture sorption characteristics and modeling of energy sorghum 
(Sorghum bicolor (L.) Moench). Journal of Stored Products Research. 2013;52:128-36.

[78] He X, Lau AK, Sokhansanj S, Lim CJ, Bi XT, Melin S, et al. Moisture sorption isotherms and drying characteristics of aspen (Populus tremuloides). Biomass and Bioenergy. 2013;57:161-7.

[79] Mann BF, Chen H, Herndon EM, Chu RK, Tolic N, Portier EF, et al. Indexing permafrost soil organic matter degradation using high-resolution mass spectrometry. PLoS ONE. 2015;10:e0130557.

[80] Yu X, Makkawi Y, Ocone R, Huard M, Briens C, Berruti F. A CFD study of biomass pyrolysis in a downer reactor equipped with a novel gas-solid separator - I: Hydrodynamic performance. Fuel Processing Technology. 2014;126:366-82.

[81] Mason PE, Darvell LI, Jones JM, Williams A. Comparative study of the thermal conductivity of solid biomass fuels. Energy \& Fuels. 2016;30:2158-63.

[82] Dahlquist E. Technologies for Converting Biomass to Useful Energy: Combustion, Gasification, Pyrolysis, Torrefaction and Fermentation: Taylor \& Francis; 2013.

[83] Dupont C, Chiriac R, Gauthier G, Toche F. Heat capacity measurements of various biomass types and pyrolysis residues. Fuel. 2014;115:644-51.

[84] Basu P. Biomass Gasification, Pyrolysis and Torrefaction: Practical Design and Theory: Elsevier Science; 2013.

[85] Karunanithy C, Muthukumarappan K, Donepudi A. Moisture sorption characteristics of corn stover and big bluestem. Journal of Renewable Energy. 2013;2013:Article ID 939504.

[86] Basu P. Chapter 3 - Biomass Characteristics. Biomass Gasification, Pyrolysis and Torrefaction (Second Edition). Boston: Academic Press; 2013. p. 47-86.

[87] Vassilev SV, Baxter D, Andersen LK, Vassileva CG. An overview of the composition and application of biomass ash. Part 1. Phase-mineral and chemical composition and classification. Fuel. 2013;105:40-76.

[88] Nunes LJR, Matias JCO, Catalão JPS. Biomass combustion systems: A review on the physical and chemical properties of the ashes. Renewable and Sustainable Energy Reviews. $2016 ; 53: 235-42$.

[89] P Singh Chouhan A, K Sarma A. Critical analysis of process parameters for bio-oil production via pyrolysis of biomass: A review. Recent Patents on Engineering. 2013;7:98-114. 
[90] ASTM E1756 - 08, Standard Test Method for Determination of Total Solids in Biomass. West Conshohocken, PA: ASTM International; 2015.

[91] ASTM E17551 - 01, Standard Test Method for Ash in Biomass. West Conshohocken, PA: ASTM International; 2015.

[92] ASTM E872 - 82, Standard Test Method for Volatile Matter in the Analysis of Particulate Wood Fuels. West Conshohocken, PA: ASTM International; 2013.

[93] Klass DL. Biomass for Renewable Energy, Fuels, and Chemicals: Elsevier Science; 1998. [94] ASTM D7582-15, Standard Test Methods for Proximate Analysis of Coal and Coke by Macro Thermogravimetric Analysis. West Conshohocken, PA: ASTM International; 2015.

[95] García R, Pizarro C, Lavín AG, Bueno JL. Biomass proximate analysis using thermogravimetry. Bioresource Technology. 2013;139:1-4.

[96] Cantrell K, Martin J, Ro K. Application of thermogravimetric analysis for the proximate analysis of livestock wastes. Journal of ASTM International. 2011;7:Paper ID JAI102583.

[97] Jenkins B, Baxter L, Miles T. Combustion properties of biomass. Fuel Processing Technology. 1998;54:17-46.

[98] Umesh D, Sarsavadiya P, Vaja K, Mahadeo K. Physiochemical properties of cotton stalk biomass from aricultural residues. Current World Environment. 2015;10:343-9.

[99] Guo M, Bi J. Pyrolysis Characteristics of Corn Stalk with Solid Heat Carrier. BioResources. 2015;10:3839-51.

[100] Donahue CJ, Rais EA. Proximate analysis of coal. Journal of Chemical Education. 2009;86:222.

[101] Lee S, Speight JG, Loyalka SK. Handbook of Alternative Fuel Technologies, Second Edition: CRC Press; 2014.

[102] Kirmse W. Organic Elemental Analysis: Ultramicro, Micro, and Trace Methods: Elsevier Science; 2012.

[103] Van Krevelen D. Graphical-statistical method for the study of structure and reaction processes of coal. Fuel. 1950;29:269-84.

[104] Lv P, Xiong Z, Chang J, Wu C, Chen Y, Zhu J. An experimental study on biomass airsteam gasification in a fluidized bed. Bioresource Technology. 2004;95:95-101.

[105] Vassilev SV, Kitano K, Vassileva CG. Some relationships between coal rank and chemical 
and mineral composition. Fuel. 1996;75:1537-42.

[106] Chen Z, Zhang S, Chen Z, Ding D. An integrated process for hydrogen-rich gas production from cotton stalks: The simultaneous gasification of pyrolysis gases and char in an entrained flow bed reactor. Bioresource Technology. 2015;198:586-92.

[107] Miller FP, Vandome AF, John MB. Higher Heating Value: VDM Publishing; 2010.

[108] Demirbas A. Effects of moisture and hydrogen content on the heating value of fuels. Energy Sources, Part A: Recovery, Utilization, and Environmental Effects. 2007;29:649-55.

[109] THEK G, OBERNBERGER I. An integrated European market for densified biomass fuels (INDEBIF). Austrian Country Report (final Report), EU-ALTENER-Projekt AL/98/520, BIOS BIOENERGIESYSTEME GmbH (Ed), Graz, Austria. 2002.

[110] Demirbaş A. Relationships between lignin contents and heating values of biomass. Energy Conversion and Management. 2001;42:183-8.

[111] Williams CL, Westover TL, Emerson RM, Tumuluru JS, Li C. Sources of biomass feedstock variability and the potential impact on biofuels production. BioEnergy Research. 2016;9:1-14.

[112] Boundy RG, Diegel SW, Wright LL, Davis SC. Biomass Energy Data Book: Department of Energy, United States; 2011.

[113] Wu W, Mei Y, Zhang L, Liu R, Cai J. Kinetics and reaction chemistry of pyrolysis and combustion of tobacco waste. Fuel. 2015;156:71-80.

[114] Lebo SE, Gargulak JD, McNally TJ. Lignin. Kirk-Othmer Encyclopedia of Chemical Technology: John Wiley \& Sons, Inc.; 2000.

[115] Yang H, Yan R, Chen H, Lee DH, Zheng C. Characteristics of hemicellulose, cellulose and lignin pyrolysis. Fuel. 2007;86:1781-8.

[116] Pérez J, Munoz-Dorado J, de la Rubia T, Martinez J. Biodegradation and biological treatments of cellulose, hemicellulose and lignin: an overview. International Microbiology. 2002;5:53-63.

[117] Welker C, Balasubramanian V, Petti C, Rai K, DeBolt S, Mendu V. Engineering plant biomass lignin content and composition for biofuels and bioproducts. Energies. 2015;8:7654. [118] Sluiter JB, Ruiz RO, Scarlata CJ, Sluiter AD, Templeton DW. Compositional analysis of lignocellulosic feedstocks. 1. Review and description of methods. Journal of Agricultural and 
Food Chemistry. 2010;58:9043-53.

[119] ASTM E1757 - 01, Standard Practice for Preparation of Biomass for Compositional Analysis. West Conshohocken, PA: ASTM International; 2015.

[120] Templeton DW, Scarlata CJ, Sluiter JB, Wolfrum EJ. Compositional analysis of lignocellulosic feedstocks. 2. Method uncertainties. Journal of Agricultural and Food Chemistry. 2010;58:9054-62.

[121] Cai J, Wu W, Liu R, Huber GW. A distributed activation energy model for the pyrolysis of lignocellulosic biomass. Green Chemistry. 2013;15:1331-40.

[122] Sluiter A, Hames B, Ruiz R, Scarlata C, Sluiter J, Templeton D, et al. Determination of structural carbohydrates and lignin in biomass. Laboratory Analytical Procedure: National Renewable Energy Laboratory; 2012. p. 18.

[123] Pandey A, Negi S, Binod P, Larroche C. Pretreatment of Biomass: Processes and Technologies: Elsevier Science; 2014.

[124] Roggo Y, Chalus P, Maurer L, Lema-Martinez C, Edmond A, Jent N. A review of near infrared spectroscopy and chemometrics in pharmaceutical technologies. Journal of Pharmaceutical and Biomedical Analysis. 2007;44:683-700.

[125] Jin S, Chen H. Near-infrared analysis of the chemical composition of rice straw. Industrial Crops and Products. 2007;26:207-11.

[126] Carrier M, Loppinet-Serani A, Denux D, Lasnier J-M, Ham-Pichavant F, Cansell F, et al. Thermogravimetric analysis as a new method to determine the lignocellulosic composition of biomass. Biomass and Bioenergy. 2011;35:298-307.

[127] McKendry P. Energy production from biomass (part 1): overview of biomass. Bioresource Technology. 2002;83:37-46.

[128] Mahalaxmi S, Williford C. Biochemical Conversion of Biomass to Fuels. In: Chen W-Y, Suzuki T, Lackner M, editors. Handbook of Climate Change Mitigation and Adaptation. New York, NY: Springer New York; 2014. p. 1-28.

[129] Jørgensen H, Kristensen JB, Felby C. Enzymatic conversion of lignocellulose into fermentable sugars: challenges and opportunities. Biofuels, Bioproducts and Biorefining. 2007;1:119-34.

[130] Bajpai P. Pretreatment of Lignocellulosic Biomass for Biofuel Production: Springer 49 
Singapore; 2016. 